\title{
Prestige, Status, and Esteem and the Teacher Shortage
}

\author{
Scott G. Klimek ${ }^{1}$ \\ ${ }^{1}$ Department of Educational Leadership, University of North Dakota, Grand Forks, North Dakota, USA \\ Correspondence: Dr. Scott Klimek, Department of Educational Leadership, University of North Dakota, Grand \\ Forks, ND, United States. E-mail: scott.klimek@vcsu.edu
}

Received: June 3, 2019

Accepted: July 1, 2019 Online Published: July 15, 2019

doi:10.5539/jel.v8n4p185

URL: https://doi.org/10.5539/jel.v8n4p185

\begin{abstract}
1,127 U.S. high school senior and college undergraduate perceptions of teaching's prestige, status, and esteem were explored in this study. The population consisted of 302 high school seniors and 825 college undergraduates from the Midwestern region of the United States. The study included 51 statements where participants rated their perceptions of teaching's prestige, status, and esteem on an 8-point Likert scale. The data was factor analyzed, and the results identified that the perceptions of teaching's prestige consisted of financial and image perceptions. A descriptive analysis found that U.S. high school senior and college undergraduate perceptions of teaching's financial component of prestige $(\mathrm{M}=9.99, \mathrm{SD}=2.90)$ and esteem $(\mathrm{M}=10.42, \mathrm{SD}=3.05)$ were more negative in comparison to status $(\mathrm{M}=13.38, \mathrm{SD}=2.74)$.

Bivariate correlation, Univariate, and hierarchal linear regression techniques measured the effects that the perceptions of teaching's prestige, status, and esteem had on U.S. high school seniors and college undergraduate teaching considerations. The results indicated that the perceptions of teaching's status may encourage U.S. high school seniors and college undergraduates to consider careers in teaching, but the perceptions of esteem may produce opposite effects. The results demonstrated that the perceptions of teaching's esteem may discourage U.S high school seniors and college undergraduates scoring in the upper deciles of the ACT (American College Testing) from considering teaching in the United States. The results indicated that the perceptions of esteem may also discourage U.S. urban female high school seniors and college undergraduates from considering the career. Finally, the results demonstrated the perceptions of teaching's esteem and its interaction with the financial perceptions of teaching's prestige may discourage U.S. aspiring teachers from the career. This result raises questions as to the "roots" of the early teacher attrition problem in the United States.
\end{abstract}

Keywords: teacher shortage, prestige, status, esteem, teacher retention

\section{Literature Review}

Numerous attempts to counteract teacher shortages in the United States have been employed, with such interventions as induction programs, recruitment bonuses, alternative teacher certification, and resident teacher programs (Darling-Hammond, Furger, Shields, \& Sutcher, 2016; Ronfeldt \& McQueen, 2017; Zhang \& Zeller, 2016). While some remedies have displayed some success, the problem is trending upward, with many states reporting greater challenges in acquiring teachers each year (Darling-Hammond \& Rothman, 2015; DeNisco, 2015; Gerckens, 2016). Despite efforts to offset the teacher shortage, a limited number of policies and research have aimed to improve the status, prestige, and esteem of the teaching career in the United States. Commentators report most studies examining these constructs have originated from other parts of the world, where teacher shortages are less of a problem (Ingersoll \& Merrill, 2011; Perda, 2013; Sahlberg, 2015; Simola, 2005).

Researchers investigating occupational prestige, status, and esteem have found correlations between a career's status in society and the ability to attract talented individuals (Fwu \& Wang, 2002, Hoyle, 2001; Ingersoll \& Merrill, 2011). Results from several studies have revealed that careers with low status draw less talented individuals, which decreases the ability of the career to attract quality people (Barber \& Mourshed, 2007; Towse, Kent, Osaki, \& Kirua, 2002; Wang \& Huang, 2016). Conversely, careers that are perceived to be professions attract talented people, which elevates its status. Examples of this phenomenon are found in Singapore and South Korea, where society believes that teaching is the single most important profession (Lim, 2014; Seongja, 2008). The perception of teaching in these nations has led to a large number of highly talented individuals pursuing careers in teaching (Darling-Hammond, 2017). 
Indeed, many individual teachers are well respected in U.S. schools. However, the career itself has generally been considered of a lower status than professions such as engineering, law, and medicine (Bushaw \& Lopez, 2011; Pike, 2014). For decades, educational leaders have been concerned about the career's low status and the impacts of this low status on the quality of individuals who decide to enter the field (Darling-Hammond, 2017; Lankford, Loeb, McEachin, Miller, \& Wyckoff, 2014; Wang \& Huang, 2016). Yet, these concerns have not yielded attempts to address the subject, since student achievement initiatives have superseded endeavors to advance the career's status (Auguste, Kihn, \& Miller, 2010). Countless initiatives, such as Race to the Top, No Child Left Behind, Common Core, and voucher programs have all been deployed in efforts to raise student achievement (Carey, 2017; Darling-Hammond \& Rothman, 2015; Pike, 2014; White, 2016). While each initiative has produced some level of success, evidence indicates that most outcomes have been inconsistent (DuFour \& Mattos, 2013; White, 2016). Scholars contend that these inconsistencies are the direct results of a teacher gap that requires intervention prior to staging further initiatives to address student learning gaps (Akiba, LeTendre, \& Scribner, 2007; Ronfeldt, Loeb, \& Wyckoff, 2013).

\subsection{Purpose of the Study}

The purpose of this research was two-fold. The first was to develop a set of reliable scales capable of measuring the perceptions of teaching's prestige, status, and esteem. The second was to use the scales to measure high school senior and college undergraduate perceptions of teaching's prestige, status, esteem, and to determine the level of influence the perceptions may have on each population's teaching considerations.

\subsection{Research Questions}

The following research questions guided the study:

1) How do Hoyle's occupational prestige, status, and esteem components impact high school senior and college undergraduate teaching considerations?

2) How do Hoyle's occupational prestige, status, and esteem components impact the different demographic groups of high school senior and college undergraduate teaching considerations?

3) How do Hoyle's occupational prestige, status, and esteem components impact the academic aptitudes of high school's seniors and college undergraduates considering education careers?

4) How might practices from around the world impact the perceptions of the prestige, status, and esteem of teaching as a career?

\subsection{Assumptions}

1) The instrument will elicit valid and reliable responses.

2) The participants will be able to read and understand the questions that the instrument asks and respond honestly.

\subsection{Importance of the Study}

Educational leaders are continuously pursuing methods to improve the quality of education in the United States (Rockoff, 2004). However, the shortage of qualified teachers continues to derail efforts, since teacher quality is the key element in raising student achievement (McLeskey \& Billingsley, 2008; Rivkin, Hanushek, \& Kain, 2005; Sanders \& Horn, 1998). McLeskey and Billingsley (2008) assert "the quality of the teacher contributes more to student achievement than any other factor, including class size, class composition, or student background" (p. 294). Research demonstrates that students may score up to $50 \%$ greater on achievement tests when assigned to effective teachers three years in a row (Sanders \& Rivers, 1996). Similarly, Hanushek and Rivkin (2010) found that a quality teacher can produce learning gains of 0.2 standard deviations in a year's time. These results demonstrate that a student would move from the middle of the achievement distribution to the 58th percentile. Moreover, Podgursky and Springer (2011) reported that "the achievement gap among high- and low-socioeconomic status students could be overcome if an economically disadvantaged student encountered an above average teacher for five consecutive years" (p. 170).

Conversely, evidence points to the potential dangers that may result from students receiving instruction from inadequate and unqualified teachers (Hanushek \& Rivkin, 2010). Research demonstrates that the effects of ineffective instruction can substantially impact student academic performance for multiple years (Goe, 2007; Sanders \& Horn, 1998; Sanders \& Rivers, 1996). Studies have confirmed that students assigned to an ineffective teacher for 1 school year are at-risk of having their learning impaired for several years. Similar investigations have generated substantial evidence revealing that entire academic careers may be marred when students are assigned to incompetent teachers for 2 or more years in a row (Breaux \& Wong, 2003; Hanushek \& Rivkin, 2010; 
Sanders \& Horn, 1998; Sanders \& Rivers, 1996).

The consequences of a growing number of inadequate and unqualified teachers entering the nation's classrooms can be observed every three years when the Programme for International Student Assessment (PISA) results are published (Darling-Hammond \& Rothman, 2015). PISA is an international assessment that was developed by the Organization for Economic Cooperation and Development (OECD) in the 1990s in response to requests from member nations searching for performance data on student and educational systems. The first PISA assessment was administered to 15-year olds in 43 different nations in 2000. Since that time, more than 70 countries have participated in PISA, which has permitted nations to compare student knowledge and learn from one another (PISA, 2014).

Since its inception, PISA student achievement data have demonstrated that U.S. students consistently lag a considerable distance behind students in many of the world's major nations (Fleischman, Hopstock, Pelczar, \& Shelley, 2010; Hanushek, Peterson, Woessmann, 2012; Kastberg, Chan, \& Murray, 2017). The results have produced concern, leading federal and state entities to develop standards and disseminate high stakes assessments to ensure student growth (U.S. Department of Education, 2010). However, the literature reports that the era of standardized education in America has produced mixed results in student learning (Braun, Wang, Jenkins, \& Weinbaum, 2006; Reback, 2008).

The introduction of PISA has generated a body of research about the relationships between occupational status and teacher recruitment and retention and student achievement (OECD, 2005). Since the first administration of PISA in 2000, PISA results have exposed consistent disparities between student performances in a number of the largest economies in the world (PISA, 2015). PISA results consistently confirm that the single variable top-performing nations share is the capacity to attract highly talented people to the teaching career (OECD, 2005; Paine \& Schleicher, 2010; Sahlberg, 2015). The status, prestige, and esteem of teaching in these nations is comparable to medicine, law, and engineering (OECD, 2010). Scholars point out that these countries "invest in the development of high-quality teachers and take steps to elevate the entire profession to a higher level of respect and regard" (Paine \& Schleicher, 2010, p. 4).

Researchers have also found that student achievement is limited in nations where the teaching career is not afforded high status, prestige, and esteem. Frequently, these nations find it difficult to recruit and retain quality individuals into teaching (Paine \& Schleicher, 2010). In a formal letter to former U.S. Secretary of Education Arne Duncan, OECD Secretary-General Angel Gurria wrote "careful consideration must go into making the teacher profession attractive; recruiting and selecting teachers; rewarding and training them on the job; recognizing the best performers and helping those who have merits but are struggling to grow" (Paine \& Schleicher, 2010, p. 4).

There is compelling evidence that demonstrates the quality of a nation's education system depends on a professional teacher workforce that is highly regarded (Paine \& Schleicher, 2010). In the U.S., teaching as a profession is not necessarily highly regarded, and its status frequently deters people from pursuing it as a career (Auguste, Kihn, \& Miller, 2010; Podgursky, Monroe, \& Watson, 2004). In the past 2 decades, numerous U.S. university systems have experienced sharp declines in the number of students enrolled in their teacher preparation programs (Aragon, 2016; National Center for Education Statistics, 2016). From 2010 through 2013, U.S. post-secondary institutions observed a $31 \%$ decrease in the number of students pursuing undergraduate degrees in education (Aragon, 2016). This amounts to nearly a 240,000 decrease (compared with 2009) in the number of qualified teachers entering the teacher pipeline (Sutcher, Darling-Hammond, \& Carver-Thomas, 2016). In conjunction with falling enrollment, the number of bachelor degrees awarded to education majors fell by $34 \%$ between the years 2003 and 2014. Of the six career fields with the most graduates, education was the single area to experience a decline in degrees conferred through this period (National Center for Education Statistics, 2016).

The rising number of untrained and inexperienced teachers entering the nation's classrooms places the education of many of the nation's children at-risk (Clotfelter, Ladd, \& Vigdor, 2007; Darling-Hammond \& Berry, 2006). Scholars note the implications these trends may have on student performance and emotional problems, and ultimately, the ability to compete within a global economy (Clotfelter, Ladd, \& Vigdor, 2007; Guha, Hyler, \& Darling-Hammond, 2017; McLeskey \& Billingsley, 2008). Leaders from around the world have recognized these detriments and have established policies to evolve teaching into a preferred career (Darling-Hammond, 2017; Dolton \& Marcenaro-Guiterrez, 2013; Sahlberg, 2015). Nations such as Finland, South Korea, Taiwan, and Singapore have become the world's leaders in their ability to attract and maintain an effective teacher workforce (Kang \& Hong, 2008; Sahlberg, 2015; Simola, 2005). The results have led all four nations to achieve robust 
student achievement scores in conjunction with rapidly growing economies (Kang \& Hong, 2008; OECD, 2012; Sahlberg, 2015).

\section{Theoretical Framework}

\subsection{Prestige}

Most people have perceptions of the different vocations that make up a nation's workforce. They have a general understanding of the skills, knowledge, and abilities required to perform duties within various occupations. More importantly, people consciously place differing careers on a hierarchical list according to prestige. Treiman (1977) indicates that this conscious comparison of prestige has implications on a career's ability to attract and retain a qualified workforce.

For decades, occupational prestige has been examined, with results indicating that considerable differences exist in the social status of careers that form the U.S. labor market (Goyder, 2005; Pike, 2014). Much of this research suggests that university graduates are generally sensitive to social perceptions and are driven to pursue more prestigious occupations. Findings also reveal that careers that support the common good of society are frequently deemed unworthy and are regularly overlooked (Hoyle, 2001). Frequently, these fields lack the tangible rewards that society uses to measure prestige (Treiman, 1977). "Thus, these occupations like teaching are given an essentially negative social standing” (Hoyle, 2001, p. 144).

The relationships between income and an occupation's prestige sheds light on the social ranking of teachers and, perhaps, the value society bestows upon the teaching career (Zhan, 2015). The Organisation for Economic Co-operation and Development (OECD) reported in 2015 that the average veteran teacher (with 15 years of experience) in the United States earned nearly 30\% less than individuals working in careers requiring comparable college degrees (Startz, 2016; Organization for Economic Co-operation and Development, 2015). In contrast, the report demonstrated that the average Finnish veteran teacher (with 15 years of experience) earned $9 \%$ less than others associated with occupations requiring similar university training (Startz, 2016; OECD, 2015). The wider gap in U.S. teacher salaries, compared to nations that exhibit high student achievement illustrates the value a country such as Finland places upon the teaching career (Dillon, 2011; Startz, 2016). In order for U.S. teacher salaries to reach Finnish teacher compensation levels, primary school teacher salaries would need to increase by $10 \%$, elementary school teacher salaries would need to increase by $18 \%$, and secondary teacher compensation would need to increase by $28 \%$ (OECD, 2015; Startz, 2016).

Like compensation, a career's image impacts the level of prestige a society grants it (Goyder, 2005; Mensah, 2011; Hargreaves \& Hoyle, 2001). Hoyle (2001) hypothesized that the image children acquire from interactions with teachers is a substantial component that subdues the teaching career's prestige. His claim centers on the hypothesis that prestige is gained by images clients gain from interactions with professionals (Lankford et al., 2014). In a school environment, a number of children are reluctant to participate. This reluctance leads to the potential for disorder. Hoyle (2001) affirms that the image of school as a place of disorder shapes the image of teaching as a career. The need to maintain order, and the consequences of loss of control, reduce prestige.

Hoyle (2001) hypothesizes that the image of teaching has been stimulated by its intermediate position. He illustrates this idea of intermediacy through a common canard depicting the perception of a male teacher as "a man amongst boys and a boy amongst men" (p. 144). This canard illustrates a common perception that the teacher is able to prepare students for the real world. However, teachers remain between the "world of school" and the "real world" while their students move forward.

Hoyle (2001) theorizes that teachers generally remain in intermediate positions because of natural ambiguities that accompany the career. This theory stems from students "accomplishing" school and moving beyond its world. "The teacher thus becomes a symbol of the dependent social role which they have left behind" (Hoyle, 2001, p. 144). Most importantly, he contends that the career's ambiguities and its intermediacy will continue to limit the level of prestige teaching may be able to achieve (Hoyle, 2001).

\subsection{Status}

Members of the education community commonly refer to teaching as a profession. However, research illustrates that it is not universally accepted as such (Hargreaves, 2009; Hoyle, 2001; Ingersoll \& Merrill, 2011). Reports imply that policymakers' decisions to initiate additional accountability measures may not have centered exclusively on student achievement, but also on teacher status concerns (Fuller, Goodwyn, \& Francis-Brophy, 2013). These added expectations have been the driving force behind school districts requiring their practitioners to incorporate scripted lessons, adhere to pacing guides, use pre-determined examinations, and assure students pass high-stakes assessments. Scholars attest that the results of this standardization of education have not 
elevated status, but have encouraged the general public to further question the capabilities of the U.S. teacher workforce (Croft, Roberts, \& Stenhouse, 2016). Research has found that this movement toward tighter control has further crippled the status of teaching (Fuller et al., 2013). Fuller et al. (2013) assert "when autonomy and responsibility are removed through the implementation of rigid standards to be adhered to, professional status is in fact diminished."

A career's professional status hinges on the composition of its workforce (Fuller et al., 2013; Hoyle, 2001). Several studies demonstrate that a career is generally perceived to be a profession when it is composed of educated individuals that possess specific abilities, talents, and aptitudes (Hargreaves, 2009; Ingersoll \& Merrill, 2011; Lankford et al., 2014). Workers in professions acquire higher social standing when other professional groups recognize their status (Hoyle, 2001). A career's professional social standing is also contingent upon the perceptions of the specialized knowledge and skills that are required to perform the career (Ingersoll \& Merrill, 2011). Finally, an occupation's professional status is dependent upon the career's "rigorous training, licensing requirements, positive working conditions, an active professional organization, substantial workplace authority, relatively high compensation, and high prestige" (Ingersoll \& Merrill, 2011, p. 186).

The meaning of status lies within the perceptions of knowledgeable groups (Hargreaves, 2009; Hoyle, 2001). For teaching, these views pose roadblocks and interfere with its ability to gain professional identity and improve its status (Croft et al., 2016). This phenomenon appears to have originated from perceptions that the training preservice teachers receive at the postsecondary level is far less rigorous than training for other fields of study (Ingersoll \& Merrill, 2011; Hargreaves, 2009; Hoyle, 2001). These views regularly lead members of the public to perceive teaching as a career that ordinary individuals with a general understanding of mathematics and literacy can perform (Darling-Hammond \& Rothman, 2015; Hargreaves, Cunningham, Hansen, McIntyre, \& Oliver, 2007; Lankford et al., 2014; Mackenzie, 2007).

\subsection{Esteem}

Esteem is often associated with perceptions of prestige and status. Although relationships exist between esteem, prestige, and status, scholars say that esteem differs from prestige and status, since occupations can be esteemed but still lack prestige and status (Hoyle, 2001). This theory is demonstrated in nations such as Portugal, where teachers are perceived to embody the characteristics of esteem, but the esteem does not translate into greater status (Dolton \& Marcenaro-Guiterrez, 2013; Hoyle, 2001). V.S Naipaul's literary piece captures this phenomenon through a six-year old Indian boy explaining his perceptions of a teacher (Hoyle, 2001). The boy states "he's like that because he's a poor man. He's a teacher whom one respects, but really he is a poor man" (Hoyle, 2001, p. 147).

Attempts to erode the teaching career's esteem in the United States are frequently observed through the media's portrayal of teaching (OECD, 2005). As with other occupations, some teachers inevitably stray from standards related to esteem. Media stories report these lapses, which produce negative images of teachers and the career (Hoyle, 2001).

Motion pictures and television shows also play a role in eroding the teaching career's esteem (Mackenzie, 2007). Frequently, media skew the perceptions of teachers by inaccurately stereotyping the workforce (Mensah, 2011). Swetnam (1992) studied misrepresentations of teachers and found that "without personal knowledge about schools and teachers, people form their attitudes based on fictional media representations" (p. 30). Frequently, teachers are portrayed as irresponsible, untrustworthy, less than professional, or miracle workers (Swetnam, 1992). More importantly, films have reinforced the perceptions that teaching is an undemanding job and that anyone can teach. Rarely do films present teachers planning, grading papers, handling difficult behaviors, struggling with little resources, or facing other demands the career requires (Mackenzie, 2007; Mensah, 2011).

Along with the media, political "bashing" and blaming teachers for society's social ills have held the career's esteem hostage (Auguste et al., 2010; Goldstein, 2011). Scholars assert that to enhance esteem, the discourse must become positive, so that the public can create a favorable image of teachers (Hoyle, 2001). Nonetheless, reversing the discourse is problematic with a twenty-four-hour news cycle that frequently criticizes the career (Auguste et al., 2010).

\subsection{Semantic Status}

A career realizes semantic status when a society holds positive perceptions of prestige, status, and esteem (Hoyle, 2001). This is a powerful ideology considering that a large number of graduates may be attracted to the idea of being a "professional" in a high-status occupation. Many assume that the fruits of their labor will be sweeter and the rewards will be plentiful. In contrast, occupations with formal status may be given a professional label by a 
governing body, but its professional status may not be absolute (Hoyle, 2001). Internally, its workforce may perceive itself to be a profession, but externally, society may hold differing perceptions. Hoyle (2001) contends that careers with semantic status are considered to be highly regarded and are able to recruit larger pools of quality applicants.

\section{Methods}

\subsection{The Survey Instrument}

The survey instrument's framework originated from the work of Hoyle and the Teacher Status Project. Its questions were formulated from Hoyle's three dimensions of semantic status (prestige, status, and esteem), and statements that appeared in the Teacher Status Project. While decisions were made to include a number of the original statements from the Teacher Status Project, the majority were modified to address the present study's research questions (Hargreaves et al., 2007; Hoyle, 2001). Moreover, questions were formulated specifically for the statistical methods that were used in the analysis.

The instrument contained an eight-point Likert scale that was designed to measure participants' perceptions of the teaching career's prestige, status, and esteem. It included 17 questions that were divided into 6 sections, with the first seeking demographic information. In this section, participants were asked to respond to 8 questions, which ranged from family financial status to ACT score information (e.g., Please indicate your career aspirations, Please choose one of the following that best describes your hometown. What was your act score?, Please select one of the following that best describes your parent's/family income, Select description that best describes you). The section concluded with a question that served as a dependent variable throughout the analysis (To what degree have you considered teaching as a career?).

Section II asked participants to respond to questions concerning their perceptions of the teaching career's prestige. This section included 16 statements, ranging from the perceptions of teacher salaries to the image of the teaching career (e.g., Teachers earn an appropriate salary, The public has a positive image of the teaching career, The image of the classroom environment produces positive images of teaching, The teaching career offers promotion opportunities, Teachers earn a salary that allows them to feel financially secure). The section concluded with a question that served as a dependent variable throughout the analysis (To what degree do the perceptions of the teaching career encourage or discourage you to become a teacher?).

Section III asked participants to respond to questions concerning their perceptions of the teaching career's status. This section included 13 statements ranging from the perceptions of the knowledge and abilities of the workforce and the career's professional status (e.g., The workforce has teachers who are recognized to have expertise in certain areas, Teaching positions are competitive, Teaching is a highly sought after career, Teaching is considered a professional career, Teachers exhibit a high level of work performance, The teacher workforce is comprised of skilled individuals). Section III concluded with a question that served as a dependent variable throughout the analysis (To what degree do the perceptions of the teaching career's professional status encourage or discourage you to become a teacher?).

Section IV asked participants to respond to questions concerning their perceptions of the teaching career's esteem. This section included 12 items that ranged from the media portrayal of the teaching career to respect (The government values the teaching career, Teachers are trusted by the wider community, Teachers have the respect of their students, The public values the teaching career, Teachers have the respect of community members).

Section $\mathrm{V}$ followed, asking participants to respond to questions concerning their considerations to teach if their perceptions of prestige, status, and esteem were different. This section included 18 items that addressed topics such as teacher compensation and the career's professional status (Society has a high regard for the teaching career, The teaching career offers full-retirement at 50, The teaching career is considered a high status occupation, Teaching careers offer salary levels similar to comparable professions, Teaching careers offer cost of living stipends while students attend teacher education training). This section concluded with a question that served as a dependent variable throughout the analysis (To what degree would you consider the teaching career if you perceived the aforementioned statements in question 15 to be true?).

Finally, Section VI measured the knowledge each participant felt they had in answering the survey instrument's questions (e.g., Did you feel knowledgeable in answering the survey questions?). This question served to support the validity of the data.

\subsection{Participants}

A total of 1,502 U.S. high school seniors and college undergraduates from 5 Midwestern universities, 6 
Midwestern rural public school systems, 4 Midwestern urban cluster public school systems, 1 Midwestern urban cluster private school system, and 2 Midwestern urban public school systems participated in the study. A total of 302 high school seniors and 825 college undergraduates were retained, because they indicated sufficient knowledge in answering the survey instrument's questions. In contrast, 189 high school seniors and 186 college undergraduate participants reported insufficient knowledge of the teaching career and were excluded from further analysis. The sample population represents $2 \%$ of the total possible responses $(1,127$ participants vs. 67,546 total possibilities).

\subsection{Data Collection Procedures}

Prior to launching the study, the investigator sought written consent from each public schools superintendent. The approval documents that were received were included with the required Institutional Review Board forms that were submitted to the University of North Dakota's Institutional Review Board.

Immediately following approval from UND's Institutional Review Board, the investigator dispersed an email to participating high school counselors and principals. The email included a brief explanation of the study and information detailing an opportunity to win one of two $\$ 50.00$ VISA cards. More importantly, the email requested principal support and high school counselor assistance in dispersing the survey link to high school seniors.

The approval from UND's Institutional Review Board also set in motion undergraduate recruitment procedures. Phone contacts were made to each of the involved study locations' Institutional Review Boards. Three of the Institutional Review Boards honored UND's Institutional Review Board's approval and allowed for the study to immediately commence. The other requested additional information specific to its university. The investigator submitted the required documents and the Institutional Review Board approved the study.

Immediately following the approval from each respective Institutional Review Boards, the investigator sent an email contact to participating university department chairs requesting assistance in forwarding the student recruitment letter to their undergraduate populations. The initial email highlighted an opportunity for department chairs to win one of two $\$ 50.00$ VISA cards. Department chairs who included the investigator's email address in the forward to undergraduates automatically were registered for the department chair drawing.

Participants (both undergraduates and high school seniors) also had an opportunity to win one of two $\$ 50.00$ VISA cards by completing the instrument. The recruitment letter (forwarded by counselors and university department chairs) and the informed consent page at the start of the survey outlined this information for students prior to the start of the study. Students who chose to participate were made aware of the specific registration procedures for the VISA cards at the conclusion of the study. Directions prompted interested participants to follow a link to a separate Qualtrics page. This page provided participants a space to input their first name and email address. This procedure eliminated linking identifiable information to survey data.

\section{Data Analysis}

Raw data from 1,127 participants were transferred from Qualtrics and placed into SPSS. The data were subjected to 12 Principal Axis Factor Analyses with Direct oblimin rotation. 9 bivariate correlation studies were used to examine the relationships between several populations of high school senior and college undergraduate perceptions of teaching's prestige, status, esteem, and their teaching considerations. 9 hierarchical linear regressions were also used because correlation does not suggest causation. The analyses examined several populations of high school senior and college undergraduates and their perceptions of teaching's prestige, status, and esteem, and measured the effects that the perceptions have on their teaching considerations.

The final phase of the analysis investigated the impact of international education policy on the perceptions of teaching's prestige, status, and esteem, and whether improvements in the perceptions of teaching increase high school senior and college undergraduate interest in teaching. A number of independent $t$-tests were used throughout this segment of the study to determine if policy intended to improve teaching's prestige, status, and esteem increased interest in teaching. Multiple bivariate correlation analyses were also used to examine the relationships between several populations of high school seniors and college undergraduates and their post-policy perceptions of teaching's prestige, status, and esteem, and their post-policy teaching considerations. Lastly, numerous hierarchical linear regressions examined several populations of high school seniors and college undergraduates and their post-policy perceptions of teaching's prestige, status, and esteem, and measured the effects that the perceptions have on post-policy teaching considerations.

\subsection{Demographic Variables}

The demographics in Table 1 present that a total of 1,502 participants participated in the study, 375 (27\%) 
participants reported a lack of knowledge in answering the survey instrument's questions. This result was concerning, and prompted the removal of all 375 participants from further analysis. The demographic data (Table 1) demonstrate that a larger number of female $(69 \%)$ than male $(30 \%)$ participants participated in the study. Additionally, the results illustrate that a larger number of undergraduate students (73\%) participated in the study as compared to high school seniors (27\%). The demographics also (Table 1) present that the majority of the undergraduate $(58 \%)$ and high school senior $(85 \%)$ populations reported interest in careers other than teaching.

Table 1. Demographics

\begin{tabular}{|c|c|c|}
\hline Item & $\mathrm{N}$ & Percent \\
\hline Total Respondents & 1,502 & \\
\hline \multicolumn{3}{|l|}{ Knowledge of Questions } \\
\hline Yes & 1,127 & $73 \%$ \\
\hline No & 375 & $27 \%$ \\
\hline \multicolumn{3}{|l|}{ Main Source of Information } \\
\hline Family & 241 & $21 \%$ \\
\hline Teachers, Administrators & 631 & $56 \%$ \\
\hline Experiences & 113 & $10 \%$ \\
\hline Other & 142 & $13 \%$ \\
\hline \multicolumn{3}{|l|}{ Gender } \\
\hline Male & 342 & $30 \%$ \\
\hline Female & 778 & $69 \%$ \\
\hline Other & 7 & $1 \%$ \\
\hline \multicolumn{3}{|l|}{ Ethnicity } \\
\hline Caucasian & 975 & $86 \%$ \\
\hline Minority & 152 & $14 \%$ \\
\hline \multicolumn{3}{|l|}{ Parent/Family Annual Income } \\
\hline Less than $\$ 50,000$ & 255 & $23 \%$ \\
\hline$\$ 50,000$ to $\$ 100,000$ & 266 & $24 \%$ \\
\hline$\$ 100,000$ to $\$ 150,000$ & 124 & $11 \%$ \\
\hline$\$ 150,000$ or greater & 454 & $40 \%$ \\
\hline \multicolumn{3}{|l|}{ ACT Score } \\
\hline 17 or less & 79 & $7 \%$ \\
\hline 18 to 20 & 132 & $12 \%$ \\
\hline 21 to 24 & 402 & $36 \%$ \\
\hline 25 to 28 & 254 & $23 \%$ \\
\hline 29 or greater & 172 & $15 \%$ \\
\hline \multicolumn{3}{|l|}{ Career Aspirations } \\
\hline High school Seniors Planning to Teach & 45 & $15 \%$ \\
\hline High School Seniors Planning on Other Career & 260 & $85 \%$ \\
\hline Undergraduates Planning to Teach & 344 & $42 \%$ \\
\hline Undergraduates Planning on Other Career & 478 & $58 \%$ \\
\hline \multicolumn{3}{|l|}{ Hometown } \\
\hline Rural & 383 & $34 \%$ \\
\hline Urban Cluster & 417 & $37 \%$ \\
\hline Urban & 327 & $29 \%$ \\
\hline
\end{tabular}

\subsection{Scales}

\subsubsection{Prestige Scale}

The data analysis began with a Principal Axis Factor Analysis with Direct oblimin rotation on the 16 items that formed the prestige scale. The suitability of the factor analysis was assessed by using a Kaiser-Meyer-Olkin $(\mathrm{KMO})$ measure $(\mathrm{KMO}=.85)$ and a Bartlett's Test of Sphericity $(\mathrm{p}=.00)$. The results of each measure found the data factorable. Subsequently, the factor analysis was employed, and 4 loads with eigenvalues greater than 1 were produced. A review of the output led to the decision to remove items that cross loaded with other factors.

The final factor analysis included 6 items from the prestige scale (retirement plan, benefits, salary financially secure, general public perception, image of classroom, positive image). A Kaiser-Meyer-Olkin (KMO) measure $(\mathrm{KMO}=.70)$ and a Bartlett's Test of Sphericity $(\mathrm{p}=.00)$ demonstrated that the data was factorable. The analysis, using Principal Axis Factoring and Direct oblimin rotation, produced 2 factors with eigenvalues greater than 1 
(Table 2).

The first factor (Table 2), prestige financials, produced an eigenvalue of 2.73 and explained $46 \%$ of the total variance. A follow-up examination (Table 3) of the scale's skewness (-.01) and kurtosis (.15) affirmed its normal distribution (within the acceptable +1 and -1 range) (Chan, 2003). The variable (Table 2) was subjected to a Cronbach's Alpha with results indicating acceptable internal reliability $(a=.76)$.

Table 2. Prestige scales

\begin{tabular}{lll}
\hline Item & Prestige Financials & Prestige Image \\
\hline benefits & .88 & \\
retirement plan & .88 & \\
salary financially secure & .69 & .90 \\
general public perception & & .86 \\
positive image & & .56 \\
image of classroom & & 1.20 \\
Eigenvalues & 2.73 & $67 \%$ \\
\% Variation & $46 \%$ & .69 \\
$a$ & .76 & \\
\hline
\end{tabular}

The second factor (Table 2), prestige image, produced an eigenvalue of 1.2 and explained $67 \%$ of the total variance. An examination (Table 3) of the scale's skewness (-.31) and kurtosis (-.07) demonstrated normal distribution (within the acceptable +1 and -1 range) (Chan, 2003). The variable (Table 2) was subjected to a Cronbach's Alpha with results indicating acceptable internal reliability $(a=.69)$.

\subsubsection{Descriptive Statistics}

The variable summary table (Table 3 ) demonstrates the skewness and kurtosis for the majority of the items fell within the acceptable range of +1.0 and -1.0 (Chan, 2003). The data indicate that each variable was normally distributed, despite a few items such as hometown, parent's income, how much consider teaching, and status falling just outside the acceptable range. This is not cause for alarm, given that the skewness and kurtosis of each item in question are in close proximity to the +1 and -1 acceptable range (Chan, 2003).

Table 3. Variable summary table

\begin{tabular}{llllllll}
\hline Item & $\mathrm{N}$ & $M$ & $S D$ & Min & Max & Skewness & Kurtosis \\
\hline males & 342 & 1.70 & .48 & 1.00 & 3.00 & -.63 & -.85 \\
females & 778 & 1.70 & .48 & 1.00 & 3.00 & -.63 & -.85 \\
other & 7 & 1.70 & .48 & 1.00 & 3.00 & -.63 & -.85 \\
main source & 1127 & 2.55 & .94 & 1.00 & 4.00 & -.55 & -.78 \\
hometown & 1127 & 1.95 & .79 & 1.00 & 3.00 & .09 & -1.40 \\
parent's income & 1099 & 2.71 & 1.22 & 1.00 & 4.00 & -.19 & -1.59 \\
act score & 1039 & 3.30 & 1.19 & 1.00 & 8.00 & -.22 & -.48 \\
how much consider & 1127 & 3.91 & 2.21 & .00 & 8.00 & -.13 & -1.42 \\
prestige financials & 1127 & 9.99 & 2.90 & 2.33 & 18.67 & -.01 & .15 \\
prestige image & 1127 & 11.19 & 3.05 & 2.33 & 18.67 & -.31 & -.07 \\
status & 1087 & 13.38 & 2.74 & 2.33 & 18.67 & -.77 & 1.51 \\
esteem & 1032 & 10.42 & 3.05 & 2.33 & 18.67 & -.35 & -.14 \\
policy intervention prestige & 1028 & 8.41 & 3.97 & 2.33 & 18.67 & .49 & -.54 \\
policy intervention status & 1028 & 11.76 & 2.97 & 2.33 & 18.67 & -.29 & .50 \\
policy intervention teaches & 1028 & 4.62 & 2.44 & .00 & 8.00 & -.26 & -.93 \\
policy intervention esteem & 1028 & 15.05 & 3.47 & 3.00 & 24.00 & -.57 & .96 \\
esteem x prestige financials & 1032 & 118.45 & 54.47 & 6.22 & 342.22 & .33 & .22 \\
status x esteem & 1022 & 143.76 & 53.48 & 5.44 & 384.44 & .24 & .30 \\
m. source x esteem x p. financials & 1032 & 301.09 & 180.77 & 7.78 & 1026.7 & .68 & .21 \\
p. intervention prestige x status & 1028 & 106.45 & 68.61 & 5.44 & 348.44 & 1.15 & 1.23 \\
\hline
\end{tabular}

\subsubsection{Status Scale}

A Principal Axis Factor Analysis with Direct oblimin rotation was used in the analysis of the 13 items that formed the status scale. The suitability of the factor analysis was assessed by using a Kaiser-Meyer-Olkin (KMO) 
measure $(\mathrm{KMO}=.88)$ and a Bartlett's Test of Sphericity $(\mathrm{p}=.00)$. The results of each measure found the data factorable. Subsequently, the factor analysis was run, and 3 loads with eigenvalues greater than 1 were produced. A review of the output led to the decision to remove items that cross loaded with other factors.

The final factor analysis (Table 4) included 3 items from the status scale (intellectually demanding, skilled individuals, high level work performance). A Kaiser-Meyer-Olkin $(\mathrm{KMO})$ measure $(\mathrm{KMO}=.71)$ and a Bartlett's Test of Sphericity $(\mathrm{p}=.00)$ indicated the data was factorable. The factor analysis using Principal Axis Factoring and Direct oblimin rotation produced a 1 factor load with an eigenvalue of 2.178 (Table 4). The items, intellectually demanding, high level work performance, and skilled individuals explained $73 \%$ of the total variance. A follow-up examination (Table 3) of the status scale's skewness (-.77) and kurtosis (1.51) demonstrated that the data was slightly outside the acceptable +1 and -1 range (Chan, 2003). Finally, the status variable (Table 4) was subjected to a Cronbach's Alpha with results indicating relatively high internal reliability $(\mathrm{a}=.81)$.

Table 4. Status scale

\begin{tabular}{ll}
\hline Item & Status \\
\hline intellectually demanding & .87 \\
skilled individuals & .84 \\
high level work performance & .84 \\
Eigenvalues & 2.178 \\
$\%$ Variation & $73 \%$ \\
$a$ & .81 \\
\hline
\end{tabular}

\subsubsection{Esteem Scale}

A Principal Axis Factor Analysis with Direct oblimin rotation was used in the analysis of the 12 items that formed the esteem scale. The suitability of the factor analysis was assessed by using a Kaiser-Meyer-Olkin $(\mathrm{KMO})$ measure $(\mathrm{KMO}=.86)$ and a Bartlett's Test of Sphericity $(\mathrm{p}=.00)$. The results of each measure found the data factorable. Subsequently, the factor analysis was run, and 2 loads with eigenvalues greater than 1 were produced. A review of the output led to the removal of items that cross loaded with other factors.

The final analysis (Table 5) included 3 items from the esteem scale (government values, government respects, and public values). A Kaiser-Meyer-Olkin $(\mathrm{KMO})$ measure $(\mathrm{KMO}=.66)$ and a Bartlett's Test of Sphericity (p $=.00$ ) indicated that the 3 items were factorable. The factor analysis using Principal Axis Factoring and Direct oblimin rotation produced 1 load with an eigenvalue of 2.23 (Table 5). The factor esteem explained $74 \%$ of the total variance, and a follow-up examination (Table 3) of the scale's skewness (.19) and kurtosis (-.12) affirmed its normal distribution (within the acceptable +1 and -1 range) (Chan, 2003). Lastly, esteem (Table 5) was subjected to a Cronbach's Alpha with results indicating relatively high internal reliability $(a=.83)$.

Table 5. Esteem scale

\begin{tabular}{ll}
\hline Item & Esteem \\
\hline government values & .92 \\
government respect & .86 \\
public values & .80 \\
Eigenvalues & 2.23 \\
$\%$ Variation & $74 \%$ \\
$a$ & .83 \\
\hline
\end{tabular}

\subsubsection{Policy Intervention: Prestige and Status Scales}

A Principal Axis Factor Analysis with Direct oblimin rotation was used in the analysis of the 17 items that formed the policy prestige and status interventions scale. The suitability of the factor analysis was assessed by using a Kaiser-Meyer-Olkin $(\mathrm{KMO})$ measure $(\mathrm{KMO}=.95)$ and a Bartlett's Test of Sphericity $(\mathrm{p}=.00)$. The results of each measure indicated factorability. Subsequently, the factor analysis was run, and 2 loads with eigenvalues greater than 1 were produced. A review of the output led to the removal of items that cross loaded with other factors.

The final factor analysis was run with 6 items from the policy intervention scale (student teacher salaries, 
exempt from income tax, cost of living stipends, competitive positions, socially accepted profession, teacher recognition $)$. A Kaiser-Meyer-Olkin $(\mathrm{KMO})$ measure $(\mathrm{KMO}=.79)$ and a Bartlett's Test of Sphericity $(\mathrm{p}=.00)$ indicated the factorability of the 6 items. The factor analysis using Principal Axis Factoring and Direct oblimin rotation produced 2 loads with eigenvalues greater than 1 .

The first factor (Table 6) policy intervention prestige, produced an eigenvalue of 3.04 and explained $51 \%$ of the total variance. An examination (Table 3) of the scale's skewness (.34) and kurtosis (-.43) indicated normal distribution (within the acceptable +1 and -1 range) (Chan, 2003). The policy intervention prestige (Table 6) variable was subjected to a Cronbach's Alpha, with results displaying relatively high internal reliability ( $a$ $=.85$ ).

The second factor (Table 7) policy intervention status, produced an eigenvalue of 1.09 and explained $69 \%$ of the total variance. An examination (Table 3) of the scale's skewness (-.23) and kurtosis (.56) affirmed the variable's normal distribution (within the acceptable +1 and -1 range) (Chan, 2003). Finally, policy intervention status (Table 7) was subjected to a Cronbach's Alpha, with results displaying acceptable internal reliability $(a=.66)$.

Table 6. Policy intervention prestige scale

\begin{tabular}{ll}
\hline Item & Intervention Prestige \\
\hline income tax exempt & .92 \\
student teacher salaries & .88 \\
similar salary levels & .77 \\
Eigenvalues & 3.04 \\
\% Variation & $51 \%$ \\
$a$ & .85 \\
\hline
\end{tabular}

Table 7. Policy intervention status scale

\begin{tabular}{ll}
\hline Item & Intervention Status \\
\hline competitive & .78 \\
recognize teachers & .75 \\
socially accepted profession & .75 \\
Eigenvalues & 1.09 \\
$\%$ Variation & $69 \%$ \\
$a$ & .66 \\
\hline
\end{tabular}

\subsubsection{Policy Intervention: Esteem Scale}

A Principal Axis Factor Analysis with Direct oblimin rotation was used in the analysis of the 3 items (community respect, parents respect, and high regard for the career) that formed the policy esteem intervention scale (Table 8). The suitability of the factor analysis was assessed by using a Kaiser-Meyer-Olkin (KMO) measure (KMO $=.57)$ and a Bartlett's Test of Sphericity $(\mathrm{p}=.00)$. The results of each measure found the data factorable. Subsequently, the factor analysis was run, and 1 load with an eigenvalue greater than one was produced (Table 8). The factor policy intervention esteem (Table 8) produced an eigenvalue of 1.91 and explained $64 \%$ of the total variance. An examination (Table 3 ) of the scale's skewness (-.58) and kurtosis (.96) indicated normal distribution (within the acceptable +1 and -1 range) (Chan, 2003). The policy intervention esteem (Table 8) variable was subjected to a Cronbach's Alpha, with results displaying adequate internal reliability $(a=.68)$.

Table 8. Policy intervention esteem scale

\begin{tabular}{ll}
\hline Item & Intervention Esteem \\
\hline community respect & .89 \\
parents respect & .88 \\
high regard for the career & .58 \\
Eigenvalues & 1.91 \\
$\%$ Variation & $64 \%$ \\
$a$ & .68 \\
\hline
\end{tabular}

\section{Results}

The arrows connecting the perceptions of teaching's status to consider teaching in Figure 1 represents the positive 
effects the career's status may have on a large number of high school senior and college undergraduate teaching considerations. The results (Tables 9 and 10) revealed that the perceptions of teaching's status may be a reason high school seniors and college undergraduates scoring 25 to 28 on the ACT $(r=.47 ; \beta=.41)$ would consider teaching. Similarly, the results (Tables 11 and 12) demonstrated that the perceptions of teaching's status may be a reason high school seniors and college undergraduates from households with annual incomes greater than $\$ 150,000(\mathrm{r}=.44 ; \beta=.40)$ would consider the career.

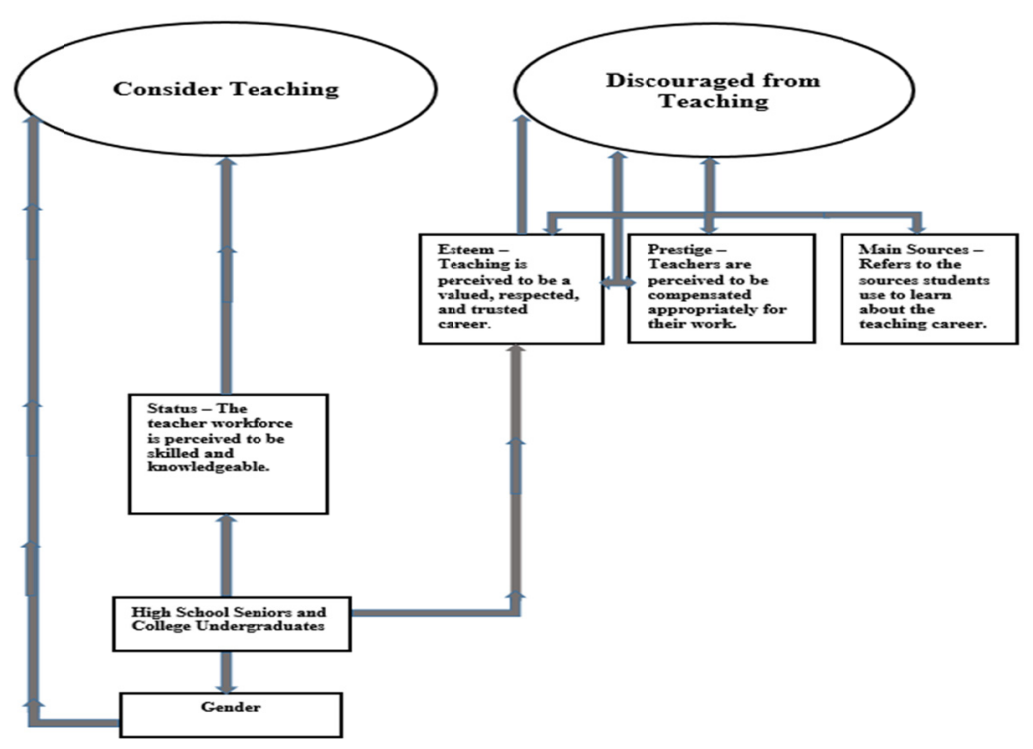

Figure 1. The visual illustrates the effects that the perceptions of teaching's prestige, status, and esteem may have on high school senior and college undergraduate teaching considerations. Additionally, the visual demonstrates that the confounding variable gender may also have an effect. The results demonstrated that females may be more likely to consider teaching than males.

Table 9. Bivariate correlation: ACT scores 25 to 28

\begin{tabular}{|c|c|c|c|c|c|c|c|c|c|}
\hline & 1 & 2 & 3 & 4 & 5 & 6 & 7 & 8 & 9 \\
\hline 1. consider teaching & - & & & & & & & & \\
\hline 2. prestige financials & .09 & - & & & & & & & \\
\hline 3. prestige image & .06 & $.32 *$ & - & & & & & & \\
\hline 4. status & $.47 *$ & .02 & $.23 *$ & - & & & & & \\
\hline 5. esteem & -.08 & .38 & $.54 *$ & .03 & - & & & & \\
\hline 6. main source & .02 & .01 & .03 & -.05 & -.02 & - & & & \\
\hline 7. parents income & .06 & -.01 & -.06 & -.05 & -.05 & -.02 & - & & \\
\hline 8. hometown & $-.14^{*}$ & -.02 & -.08 & $-.21 *$ & .10 & -.00 & .02 & - & \\
\hline 9. gender & $.26^{*}$ & $-.20 *$ & -.05 & $.18^{*}$ & -.04 & -.23 & -.08 & -.08 & - \\
\hline
\end{tabular}

Note. $\mathrm{p}<.05 *$.

Table 10. Hierarchal linear regression: ACT scores 25 to 28

\begin{tabular}{|c|c|c|c|c|c|c|c|c|c|c|}
\hline \multirow[t]{2}{*}{ Predictors } & \multicolumn{2}{|c|}{$\underline{\text { Step } 1}$} & \multicolumn{2}{|c|}{ Step 2} & \multicolumn{2}{|c|}{ Step 3} & \multicolumn{2}{|c|}{ Step 4} & \multicolumn{2}{|c|}{ Step 5} \\
\hline & $\mathrm{SE}$ & $\beta$ & SE & $\beta$ & $\mathrm{SE}$ & $\beta$ & SE & $\beta$ & $\mathrm{SE}$ & $\beta$ \\
\hline main source & .19 & .06 & .19 & .07 & .19 & .07 & .18 & .03 & .18 & .08 \\
\hline gender & .43 & $.30 *$ & .44 & $.32 *$ & .44 & $.32 *$ & .40 & $.26^{*}$ & .41 & $.24 *$ \\
\hline hometown & .23 & -.10 & .23 & -.09 & .23 & -.09 & .21 & -.01 & .21 & -.01 \\
\hline parents income & .16 & .09 & .16 & .10 & .16 & .11 & .15 & .11 & .15 & .11 \\
\hline prestige financials & & & .07 & $.16^{*}$ & .07 & .13 & .07 & $.14^{*}$ & .07 & $.16^{*}$ \\
\hline prestige image & & & & & .07 & .09 & .07 & .09 & .07 & .03 \\
\hline status & & & & & & & 06 & $42 *$ & .06 & $.41 *$ \\
\hline esteem & & & & & & & & & .07 & -.11 \\
\hline$R^{2}$ & & .11 & & .13 & & .14 & & .29 & & .30 \\
\hline
\end{tabular}


Table 11. Bivariate correlation: household income ( $\$ 150,000$ or greater)

\begin{tabular}{|c|c|c|c|c|c|c|c|c|c|}
\hline & 1 & 2 & 3 & 4 & 5 & 6 & 7 & 8 & 9 \\
\hline 1. consider teaching & - & & & & & & & & \\
\hline 2. prestige financials & .06 & - & & & & & & & \\
\hline 3. prestige image & $.11^{*}$ & $.34 *$ & - & & & & & & \\
\hline 4. status & $.44 *$ & .05 & $.26^{*}$ & - & & & & & \\
\hline 5. esteem & $-.12 *$ & $.46^{*}$ & $.61 *$ & .08 & - & & & & \\
\hline 6. act score & -.01 & -.05 & -.07 & .03 & -.04 & - & & & \\
\hline 7. main source & $.10^{*}$ & -.02 & -.05 & .04 & -.06 & -.08 & - & & \\
\hline 8. gender & $.28^{*}$ & $-.14 *$ & .02 & $.26^{*}$ & $-.16^{*}$ & .05 & $.12 *$ & - & \\
\hline 9. gender & $-.11 *$ & .01 & .02 & -.05 & .09 & $.11^{*}$ & -.08 & $-.12 *$ & - \\
\hline
\end{tabular}

Table 12. Hierarchal linear regression: household income ( $\$ 150,000$ or greater)

\begin{tabular}{|c|c|c|c|c|c|c|c|c|c|c|}
\hline \multirow[t]{2}{*}{ Predictors } & \multicolumn{2}{|c|}{ Step 1} & \multicolumn{2}{|c|}{ Step 2} & \multicolumn{2}{|c|}{ Step 3} & \multicolumn{2}{|c|}{ Step 4} & \multicolumn{2}{|c|}{ Step 5} \\
\hline & $\mathrm{SE}$ & $\beta$ & $\mathrm{SE}$ & $\beta$ & $\mathrm{SE}$ & $\beta$ & $\mathrm{SE}$ & $\beta$ & $\mathrm{SE}$ & $\beta$ \\
\hline main source & .15 & .06 & .15 & .07 & .15 & .08 & .14 & .06 & .14 & .06 \\
\hline gender & .32 & $.29 *$ & .32 & $.30^{*}$ & .32 & $.29 *$ & .30 & $.21^{*}$ & .30 & $.17^{*}$ \\
\hline hometown & .19 & -.03 & .19 & -.03 & .19 & -.03 & .17 & -.03 & .17 & -.02 \\
\hline act score & .13 & -.01 & .13 & -.01 & .13 & -.01 & .12 & -.02 & .12 & -.01 \\
\hline prestige financials & & & .05 & .09 & .05 & .05 & .05 & .07 & .05 & $.14^{*}$ \\
\hline prestige image & & & & & .05 & .09 & .05 & -.02 & .06 & .11 \\
\hline status & & & & & & & .05 & $.41^{*}$ & .05 & $.40^{*}$ \\
\hline esteem & & & & & & & & & .05 & $-.25^{*}$ \\
\hline$R^{2}$ & & .10 & & .10 & & .11 & & .25 & & .29 \\
\hline
\end{tabular}

In contrast, the arrows flowing to the right of status represent the negative effects of teaching's esteem. The results indicated that the perceptions of esteem may discourage large numbers of high school seniors and college undergraduates from considering the career. The results (Tables 13 and 14) demonstrated that high school seniors and college undergraduates from households with annual incomes ranging from $\$ 100,000$ to $\$ 150,000$ (r $=-.25, \beta=-.26$ ) may be a population discouraged by the perceptions of teaching's esteem. Moreover, the results (Tables 15 and 16) demonstrated that high school seniors and college undergraduates scoring 21 to 24 on the ACT $(r=-.18, \beta=-.30)$ may also be more likely to be discouraged by the perceptions of teaching's esteem. These results may be significant considering the size of this population. In 2018, ACT reported that the national mean composite score was 21 (ACT, 2018). This data illustrates the large number of high school seniors and college undergraduates that may be discouraged by the perceptions of teaching's esteem.

Table 13. Bivariate correlation: household income $(\$ 100,000$ to $\$ 150,000)$

The interaction variable includes status $\mathrm{x}$ esteem.

\begin{tabular}{|c|c|c|c|c|c|c|c|c|c|c|}
\hline & 1 & 2 & 3 & 4 & 5 & 6 & 7 & 8 & 9 & 10 \\
\hline 1. consider teach & - & & & & & & & & & \\
\hline 2. prestige financials & .03 & - & & & & & & & & \\
\hline 3. prestige image & .09 & $.40^{*}$ & - & & & & & & & \\
\hline 4. status & $.33^{*}$ & -.02 & .09 & - & & & & & & \\
\hline 5. esteem & $-.25^{*}$ & $.33^{*}$ & $.49^{*}$ & -.11 & - & & & & & \\
\hline 6. act score & -.11 & -.15 & -.14 & -.06 & -.16 & - & & & & \\
\hline 7. main source & -.03 & .01 & -.06 & -.18 & .05 & .04 & - & & & \\
\hline 8. gender & $.41^{*}$ & -.05 & .04 & $.23^{*}$ & $-.25^{*}$ & .09 & .01 & - & & \\
\hline 9. hometown & -.05 & .14 & .11 & -.08 & .00 & .14 & -.00 & .01 & - & \\
\hline 10. interaction & -.09 & .15 & -.02 & $.21 *$ & -.00 & .03 & .04 & $.24 *$ & -.11 & - \\
\hline
\end{tabular}

Note. $\mathrm{p}<.05^{*}$. 
Table 14. Hierarchal linear regression: household income ( $\$ 100,000$ to $\$ 150,000)$

The interaction variable includes status $\mathrm{x}$ esteem.

\begin{tabular}{|c|c|c|c|c|c|c|c|c|c|c|c|c|}
\hline \multirow[t]{2}{*}{ Predictors } & \multicolumn{2}{|c|}{$\underline{\text { Step } 1}$} & \multicolumn{2}{|c|}{ Step 2} & \multicolumn{2}{|c|}{ Step 3} & \multicolumn{2}{|c|}{ Step 4} & \multicolumn{2}{|c|}{ Step 5} & \multicolumn{2}{|c|}{ Step 6} \\
\hline & SE & $\beta$ & SE & $\beta$ & SE & $\beta$ & SE & $\beta$ & $\mathrm{SE}$ & $\beta$ & SE & $\beta$ \\
\hline main source & .28 & .03 & .28 & .03 & .30 & .03 & .28 & .07 & .27 & .08 & .26 & .08 \\
\hline gender & .53 & $.37 *$ & .53 & $.37 *$ & .53 & $.37 *$ & .53 & $.32 *$ & .54 & $.26^{*}$ & .53 & $.32 *$ \\
\hline hometown & .36 & -.10 & .36 & -.10 & .37 & -.10 & .36 & -.08 & .35 & -.09 & .34 & .12 \\
\hline act score & .23 & -.17 & .24 & -.16 & .24 & -.16 & .23 & -.15 & .23 & -.17 & .22 & -.15 \\
\hline prestige financials & & & .10 & .02 & .11 & .00 & .10 & .01 & .10 & .04 & .10 & .09 \\
\hline prestige image & & & & & .12 & .04 & .11 & .01 & .12 & .14 & .12 & .09 \\
\hline status & & & & & & & .09 & $.23 *$ & .09 & $.21^{*}$ & .09 & $.25^{*}$ \\
\hline esteem & & & & & & & & & .10 & $-.28^{*}$ & .10 & $-.26^{*}$ \\
\hline interaction & & & & & & & & & & & .03 & $-.24^{*}$ \\
\hline$R^{2}$ & & .18 & & .18 & & .18 & & .23 & & .28 & & .33 \\
\hline
\end{tabular}

Table 15. Bivariate correlation: ACT scores 21 to 24

\begin{tabular}{|c|c|c|c|c|c|c|c|c|c|}
\hline & 1 & 2 & 3 & 4 & 5 & 6 & 7 & 8 & 9 \\
\hline 1. consider teach & - & & & & & & & & \\
\hline 2. prestige financials & $.11^{*}$ & - & & & & & & & \\
\hline 3. prestige image & .08 & $.39 *$ & - & & & & & & \\
\hline 4. status & $.32 *$ & .01 & $.25^{*}$ & - & & & & & \\
\hline 5. esteem & $-.18^{*}$ & $.52 *$ & $.59^{*}$ & -.06 & - & & & & \\
\hline 6. main source & .05 & .01 & -.02 & -.01 & -.03 & - & & & \\
\hline 7. parents income & .05 & .04 & -.02 & -.04 & -.05 & -.06 & - & & \\
\hline 8. hometown & .08 & .02 & -.04 & -.07 & -.06 & -.00 & -.04 & - & \\
\hline 9. gender & $.24 *$ & $.17 *$ & -.02 & $.14 *$ & $-.16^{*}$ & .09 & -.08 & $-.11 *$ & - \\
\hline
\end{tabular}
Note. $\mathrm{p}<.05^{*}$. 9. g

Table 16. Hierarchal linear regression: ACT scores 21 to 24

\begin{tabular}{|c|c|c|c|c|c|c|c|c|c|c|}
\hline \multirow[t]{2}{*}{ Predictors } & \multicolumn{2}{|c|}{ Step 1} & \multicolumn{2}{|c|}{ Step 2} & \multicolumn{2}{|c|}{ Step 3} & \multicolumn{2}{|c|}{ Step 4} & \multicolumn{2}{|c|}{ Step 5} \\
\hline & SE & $\beta$ & $\mathrm{SE}$ & $\beta$ & SE & $\beta$ & SE & $\beta$ & SE & $\beta$ \\
\hline main source & .16 & .01 & .16 & .01 & .16 & .01 & .15 & .02 & .15 & .02 \\
\hline gender & .34 & $.25^{*}$ & .34 & $.26^{*}$ & .34 & $.26^{*}$ & .33 & $.21 *$ & .32 & $.19^{*}$ \\
\hline hometown & .19 & -.07 & .19 & -.07 & .19 & -.07 & .19 & -.05 & .18 & -.05 \\
\hline parents income & .13 & .09 & .12 & .09 & .13 & .09 & .12 & .07 & .12 & .09 \\
\hline prestige financials & & & .05 & $.12 *$ & .06 & $.12 *$ & .05 & $.16^{*}$ & .06 & $.24 *$ \\
\hline prestige image & & & & & .06 & .02 & .06 & -.07 & .06 & .08 \\
\hline status & & & & & & & .06 & $.30^{*}$ & .06 & $.25^{*}$ \\
\hline esteem & & & & & & & & & .06 & $-.30 *$ \\
\hline$R^{2}$ & & .11 & & .13 & & .14 & & .29 & & .30 \\
\hline
\end{tabular}

The arrows linking esteem and the financial component of prestige represents an interaction. The results (Tables 17 and 18) demonstrated that the perceptions of the financial component of prestige did not produce any effects on its own, but it did produce an interaction with the perceptions of teaching's esteem. The results demonstrated that the interaction $(r=-.19, \beta=-.24)$ may have an effect on the female aspiring teacher population. The results indicated that poor teacher compensation may limit the perception of teaching's esteem. These limited perceptions may be a reason that this population reconsiders their teaching intentions. These limited perceptions may also initiate thoughts of early attrition at the preservice teacher level and come to fruition once the realities of teaching are experienced. 
Table 17. Bivariate correlation: female aspiring teachers

The interaction variable includes prestige financials $\mathrm{x}$ esteem

\begin{tabular}{|c|c|c|c|c|c|c|c|c|c|}
\hline & 1 & 2 & 3 & 4 & 5 & 6 & 7 & 8 & 9 \\
\hline 1. consider teach & - & & & & & & & & \\
\hline 2. prestige financials & $.13 *$ & - & & & & & & & \\
\hline 3. prestige image & $.12^{*}$ & $.45^{*}$ & - & & & & & & \\
\hline 4. status & $.22 *$ & -.03 & .08 & - & & & & & \\
\hline 5. esteem & .04 & $.53 *$ & $.65^{*}$ & -.09 & - & & & & \\
\hline 6. act score & .06 & -.09 & $-.15^{*}$ & .10 & $-.15^{*}$ & - & & & \\
\hline 7. hometown & -.04 & -.01 & .08 & -.00 & .09 & .08 & - & & \\
\hline 8. main source & .08 & .03 & -.05 & -.03 & -.05 & -.07 & -.05 & - & \\
\hline 9. parents income & -.00 & -.04 & -.07 & .08 & -.02 & .08 & -.07 & .01 & - \\
\hline 10. interaction & $-.19 *$ & $-.48 *$ & $-.23 *$ & $.13^{*}$ & -.22 & -.07 & -.01 & -.05 & .06 \\
\hline
\end{tabular}

Table 18. Hierarchal linear regression: female aspiring teachers

The interaction variable includes prestige financials $\mathrm{x}$ esteem.

\begin{tabular}{|c|c|c|c|c|c|c|c|c|c|c|c|c|}
\hline \multirow[t]{2}{*}{ Predictors } & \multicolumn{2}{|c|}{ Step 1} & \multicolumn{2}{|c|}{ Step 2} & \multicolumn{2}{|c|}{ Step 3} & \multicolumn{2}{|c|}{ Step 4} & \multicolumn{2}{|c|}{ Step 5} & \multicolumn{2}{|c|}{ Step 6} \\
\hline & SE & $\beta$ & SE & $\beta$ & SE & $\beta$ & SE & $\beta$ & $\mathrm{SE}$ & $\beta$ & SE & $\beta$ \\
\hline main source & .08 & .04 & .08 & .04 & .08 & .05 & .08 & .05 & .08 & .05 & .08 & .03 \\
\hline hometown & .10 & -.06 & .10 & -.06 & .10 & -.06 & .10 & -.06 & .10 & -.05 & .10 & -.05 \\
\hline parents income & .06 & .02 & .06 & .03 & .06 & .03 & .06 & .02 & .06 & .03 & .06 & .03 \\
\hline act score & .08 & .04 & .08 & .05 & .08 & .05 & .08 & .02 & .08 & .02 & .08 & -.02 \\
\hline prestige financials & & & .03 & .09 & .03 & .09 & .03 & .10 & .03 & .12 & .03 & .01 \\
\hline prestige image & & & & & .03 & .01 & .03 & -.02 & .04 & .01 & .03 & -.02 \\
\hline status & & & & & & & .04 & $.21 *$ & .04 & $.20 *$ & .04 & $.24 *$ \\
\hline esteem & & & & & & & & & .03 & -.06 & .03 & -.00 \\
\hline interaction & & & & & & & & & & & .01 & $-.24 *$ \\
\hline$R^{2}$ & & .01 & & .02 & & .02 & & .06 & & .06 & & .11 \\
\hline
\end{tabular}

The arrows linking esteem, the financial component of prestige, and main sources represent an additional interaction. The results (Tables 19 and 20) demonstrated that high school seniors and college undergraduates scoring in the upper deciles of the ACT may learn of the limitations that the financial component of prestige may have on teaching's esteem from their own teachers. The demographic data (Table 1) appear to support these results, with over half $(56 \%)$ of this population reporting they learned about the teaching career from current faculty. The results demonstrated that this population may be discouraged by the effects teacher compensation may have on the perceptions on teaching's esteem. Moreover, the results raise additional questions as to the effects teacher morale may have on this population's teaching considerations.

Table 19. Bivariate correlation: ACT scores 29 or greater

The interaction variable includes main sources $\mathrm{x}$ prestige financials $\mathrm{x}$ esteem.

\begin{tabular}{llllllllll}
\hline & 1 & 2 & 3 & 4 & 5 & 6 & 7 & 8 & 9 \\
\hline 1. consider teach & - & & & & & & & & \\
2. prestige financial & -.15 & - & & & & & & & \\
3. prestige image & -.11 & $.32^{*}$ & - & & & & & & \\
4. status & $.30^{*}$ & $-.17^{*}$ & .12 & - & & & & & \\
5. esteem & $-.29^{*}$ & .46 & $.47^{*}$ & -.13 & - & & & & \\
6. main source & -.01 & .08 & .03 & -.13 & .06 & - & & & \\
7. parents income & -.00 & $.17^{*}$ & .02 & -.08 & $.17^{*}$ & -.02 & - & & - \\
8. hometown & .03 & -.01 & .13 & .13 & .10 & -.01 & -.09 & - & -.11 \\
9. gender & $.25^{*}$ & -.13 & .05 & $.27^{*}$ & -.04 & .02 & .12 & $-.25^{*}$ & - \\
10. interaction & $-.26^{*}$ & $.32^{*}$ & .06 & -.14 & $.29^{*}$ & $.40^{*}$ & -.03 & -.15 & -.11
\end{tabular}


Table 20. Hierarchal linear regression: ACT scores 29 or greater

The interaction variable includes main sources $\mathrm{x}$ prestige financials $\mathrm{x}$ esteem.

\begin{tabular}{|c|c|c|c|c|c|c|c|c|c|c|c|c|}
\hline \multirow[t]{2}{*}{ Predictors } & \multicolumn{2}{|c|}{$\underline{\text { Step } 1}$} & \multicolumn{2}{|c|}{ Step 2} & \multicolumn{2}{|c|}{$\underline{\text { Step } 3}$} & \multicolumn{2}{|c|}{ Step 4} & \multicolumn{2}{|c|}{$\underline{\text { Step } 5}$} & \multicolumn{2}{|c|}{ Step 6} \\
\hline & SE & $\beta$ & SE & $\beta$ & $\mathrm{SE}$ & $\beta$ & $\mathrm{SE}$ & $\beta$ & SE & $\beta$ & $\mathrm{SE}$ & $\beta$ \\
\hline main source & .22 & .01 & .22 & .01 & .22 & .01 & .22 & .05 & .21 & .06 & .23 & .15 \\
\hline gender & .44 & $.24 *$ & .44 & $.23^{*}$ & .45 & .25 & .45 & .16 & .44 & $.16^{*}$ & .44 & .13 \\
\hline hometown & .31 & .05 & .31 & .05 & .32 & .08 & .31 & .04 & .30 & .06 & .30 & .01 \\
\hline parents income & .18 & -.04 & .18 & -.02 & .18 & -.03 & .18 & .00 & .18 & .03 & .17 & .01 \\
\hline prestige financials & & & .07 & -.07 & .07 & -.04 & .07 & .01 & .08 & .09 & .08 & .14 \\
\hline prestige image & & & & & .08 & -.11 & .08 & -.16 & .09 & -.06 & .08 & -.07 \\
\hline status & & & & & & & .08 & $.28 *$ & .08 & $.25^{*}$ & .08 & $.26^{*}$ \\
\hline esteem & & & & & & & & & .08 & $-.26^{*}$ & .08 & $-.20^{*}$ \\
\hline interaction & & & & & & & & & & & .02 & $-.26^{*}$ \\
\hline$R^{2}$ & & .06 & & .06 & & .07 & & .14 & & .18 & & .22 \\
\hline
\end{tabular}

The results (Table 21) demonstrated that the implementation of international policy had positive effects on the majority of high school seniors $(\mathrm{M}=3.09, \mathrm{SD}=2.63 ; \mathrm{M}=3.60, \mathrm{SD}=2.49)$ and college undergraduates $(\mathrm{M}=$ $3.10, \mathrm{SD}=2.10 ; 4.16, \mathrm{SD}=2.19)$. However, the analyses were unable to establish whether improvements in the perceptions of teaching's prestige, status, and esteem led to an increased interest for all populations. For example (Table 21), males $(\mathrm{M}=3.23, \mathrm{SD}=2.79 ; \mathrm{M}=3.85, \mathrm{SD}=2.53)$ may be more likely to consider teaching with the implementation of international policy, but the researcher was unable to establish whether improvements in the aforementioned perceptions had an effect on the male population's increased interest in teaching.

Table 21. Independent t-test results

\begin{tabular}{|c|c|c|c|c|c|c|c|}
\hline & $N$ & $M(S D)$ & Range & Mean Difference & $t$ & $\mathrm{df}$ & $p$ \\
\hline \multicolumn{8}{|c|}{ college undergraduates } \\
\hline pre-policy teach & 475 & $3.10(2.10)$ & $0-8$ & 1.06 & 7.50 & 917 & $.00 *$ \\
\hline post-policy teach & 444 & $4.16(2.19)$ & $0-8$ & & & & \\
\hline \multicolumn{8}{|l|}{ high school seniors } \\
\hline pre-policy teach & 299 & $3.09(2.63)$ & $0-8$ & .51 & 2.35 & 565 & $.02 *$ \\
\hline post-policy teach & 268 & $3.60(2.49)$ & $0-8$ & & & & \\
\hline \multicolumn{8}{|l|}{ consider teach } \\
\hline male & 342 & $3.23(2.79)$ & $0-8$ & 1.72 & 4.59 & 1118 & $.00 *$ \\
\hline female & 778 & $4.95(2.77)$ & $0-8$ & & & & \\
\hline \multicolumn{8}{|c|}{ undergraduate non-aspiring teachers scoring 25} \\
\hline \multicolumn{8}{|c|}{ or greater on the ACT and deriving from } \\
\hline \multicolumn{8}{|c|}{ household with annual incomes greater than } \\
\hline \multicolumn{8}{|l|}{$\$ 50,000$} \\
\hline pre-policy teach & 170 & $2.79(2.18)$ & $0-8$ & 1.51 & - & 328 & $.00 *$ \\
\hline post-policy teach & 160 & $4.30(2.23)$ & $0-8$ & & -6.21 & & \\
\hline \multicolumn{8}{|c|}{ female urban/urban cluster seniors and } \\
\hline \multicolumn{8}{|c|}{ undergraduate non-aspiring teachers scoring 21} \\
\hline \multicolumn{8}{|c|}{ or greater on the $\mathrm{ACT}$ and deriving from } \\
\hline \multicolumn{8}{|c|}{ households with annual incomes greater than } \\
\hline \multicolumn{8}{|l|}{$\$ 50,000$} \\
\hline pre-policy teach & 133 & $3.04(2.09)$ & $0-8$ & 1.28 & 4.69 & 254 & $.00 *$ \\
\hline post-policy teach & 143 & $4.32(2.27)$ & $0-8$ & & & & \\
\hline \multicolumn{8}{|c|}{ rural/urban cluster aspiring teachers that derive } \\
\hline \multicolumn{8}{|c|}{$\begin{array}{l}\text { from households with annual incomes greater } \\
\text { than } \$ 100,000 / \text { scoring } 21 \text { or greater. }\end{array}$} \\
\hline pre-policy teach & 124 & $7.56(1.25)$ & $0-8$ & 1.27 & 5.88 & 182 & $.00 *$ \\
\hline post-policy teach & 110 & $6.28(1.94)$ & $0-8$ & & & & \\
\hline
\end{tabular}

Note. $\mathrm{p}<.05^{*}$.

Figure 2 illustrates the effects that the improvements of the perceptions of teaching's prestige, status, and esteem may have on a number of high school senior and college undergraduate populations. The results (Tables 21, 22, 
and 23) demonstrated that improved perceptions of teaching's prestige $(\mathrm{M}=2.79, \mathrm{SD}=2.18 ; \mathrm{M}=4.30, \mathrm{SD}=$ 2.23) may have a significant effect on the college undergraduate non-aspiring teacher population from households with annual incomes exceeding $\$ 50,000$ and those scoring 25 or greater on the ACT $(\mathrm{r}=.44, \beta=.35)$ Additionally, improvements (Tables 21, 24, and 25) in the perceptions of prestige $(\mathrm{M}=3.04, \mathrm{SD}=2.09 ; \mathrm{M}=$ $4.32, \mathrm{SD}=2.27$ ) may have a significant effect on the urban and urban cluster female college undergraduate non-aspiring teacher population from households with annual incomes exceeding $\$ 50,000$, and those who have scored 21 or greater on the ACT $(r=.33, \beta=.24)$. These results suggest that improvements in the perceptions of teaching's prestige could elevate teaching into being a competitive profession in the contemporary labor market. The improvements in the perceptions of teaching's prestige may be a reason that high school seniors and college undergraduates with strong academic backgrounds would consider teaching. The results also suggest that the improvements in teaching's prestige may attract a greater number of academically inclined females who would otherwise consider more prestigious professions. Finally, the results

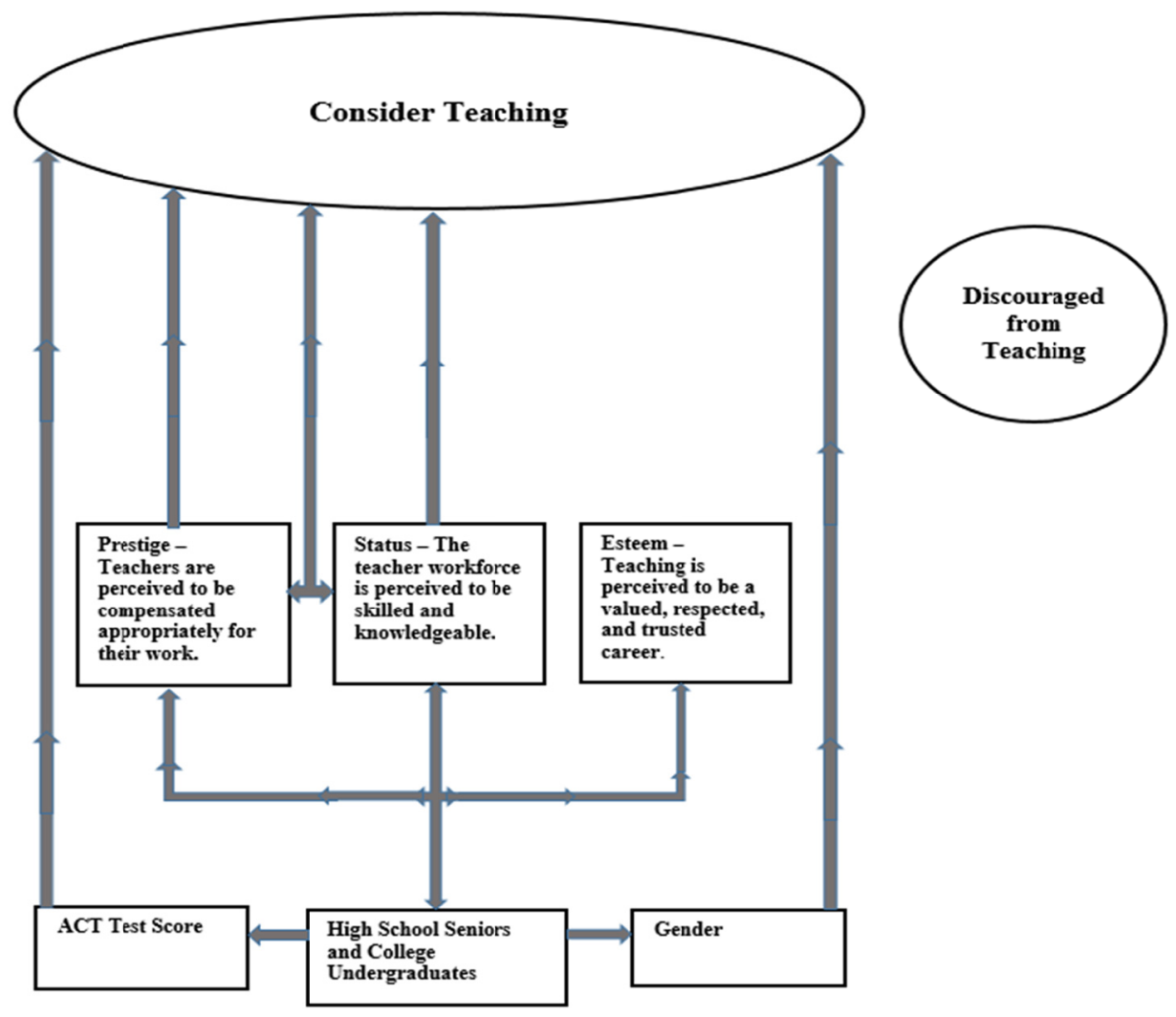

Figure 2. The visual illustrates the effects that the post-policy perceptions of teaching's prestige, status, and esteem may have on high school senior and college undergraduate teaching considerations

The visual demonstrates that improved perceptions may generate greater interest in teaching, and that the perceptions of teaching's esteem may not be a deterrent. The results demonstrated that males and high school seniors and college undergraduates scoring in the upper deciles of the ACT may also have more interest in teaching. 
Table 22. Bivariate correlation: undergraduates considering other careers

\begin{tabular}{|c|c|c|c|c|c|c|c|c|c|}
\hline & 1 & 2 & 3 & 4 & 5 & 6 & 7 & 8 & 9 \\
\hline 1. policy teach & - & & & & & & & & \\
\hline 2. policy prestige & $.44^{*}$ & - & & & & & & & \\
\hline 3. policy status & $.39 *$ & $.52 *$ & - & & & & & & \\
\hline 4. policy esteem & $.16^{*}$ & $.40 *$ & $.50 *$ & - & & & & & \\
\hline 5. gender & .11 & -.12 & -.03 & -.10 & - & & & & \\
\hline 6. act score & .03 & .12 & $.16^{*}$ & .09 & -.03 & - & & & \\
\hline 7. hometown & .07 & .13 & .05 & .12 & -.14 & .03 & - & & \\
\hline 8. main source & $-.23 *$ & $-.19 *$ & $-.27 *$ & -.08 & .05 & -.00 & .05 & - & \\
\hline 9. parents income & -.04 & .00 & -.11 & -.01 & -.03 & .03 & -.00 & -.05 & - \\
\hline
\end{tabular}

Note. $\mathrm{p}<.05^{*}$.

Table 23. Hierarchal linear regression: undergraduates considering other careers

\begin{tabular}{|c|c|c|c|c|c|c|c|c|c|c|}
\hline \multirow[t]{2}{*}{ Predictors } & \multicolumn{2}{|c|}{ Step 1} & \multicolumn{2}{|c|}{ Step 2} & \multicolumn{2}{|c|}{ Step 3} & \multicolumn{2}{|c|}{ Step 4} & \multicolumn{2}{|c|}{$\underline{\text { Step } 5}$} \\
\hline & SE & $\beta$ & SE & $\beta$ & $\mathrm{SE}$ & $\beta$ & SE & $\beta$ & SE & $\beta$ \\
\hline hometown & .25 & .08 & .24 & .10 & .22 & .05 & .22 & .05 & .22 & .05 \\
\hline parents income & .20 & -.04 & .19 & -.05 & .17 & -.05 & .17 & -.03 & .17 & -.02 \\
\hline gender & .38 & .12 & .37 & .13 & .34 & $.17^{*}$ & .34 & $.16^{*}$ & .34 & $.16^{*}$ \\
\hline act score & .36 & .03 & .35 & .02 & .32 & -.02 & .32 & -.04 & .31 & -.04 \\
\hline main source & & & .18 & $-.24 *$ & .17 & $-.16^{*}$ & .17 & -.13 & .17 & -.12 \\
\hline policy prestige & & & & & .04 & $.42 *$ & .05 & $.33 *$ & .05 & $.35^{*}$ \\
\hline policy status & & & & & & & .06 & $.19^{*}$ & .06 & $.23 *$ \\
\hline policy esteem & & & & & & & & & .06 & -.09 \\
\hline$R^{2}$ & & .02 & & .08 & & .25 & & .27 & & .28 \\
\hline
\end{tabular}

Note. $\mathrm{p}<.05^{*}$.

Table 24. Bivariate correlation: female undergraduates considering other careers

\begin{tabular}{|c|c|c|c|c|c|c|c|c|}
\hline & 1 & 2 & 3 & 4 & 5 & 6 & 7 & 8 \\
\hline 1. policy teach & - & & & & & & & \\
\hline 2. policy prestige & $.32 *$ & - & & & & & & \\
\hline 3. policy status & $.29 *$ & $.42 *$ & - & & & & & \\
\hline 4. policy esteem & $.19 *$ & $.38 *$ & $.56^{*}$ & - & & & & \\
\hline 5. act score & $.12 *$ & .11 & $.22 *$ & .06 & - & & & \\
\hline 6. hometown & .05 & .08 & .09 & $.15^{*}$ & .11 & - & & \\
\hline 7. main source & $-.12 *$ & -.05 & $-.19 *$ & -.02 & -.12 & .04 & - & \\
\hline 8. parents income & .00 & -.02 & -.06 & .02 & .09 & -.03 & -.06 & - \\
\hline
\end{tabular}

Note. $\mathrm{p}<.05^{*}$.

Table 25. Hierarchal linear regression: female undergraduates considering other careers

\begin{tabular}{lllllllll}
\hline Predictors & \multicolumn{1}{c}{ Step 1 } & \multicolumn{3}{c}{ Step 2 } & \multicolumn{3}{c}{ Step 3 } & \multicolumn{3}{c}{ Step 4 } \\
\cline { 2 - 7 } & SE & $\beta$ & SE & $\beta$ & SE & $\beta$ & SE & $\beta$ \\
\hline main source & .14 & -.10 & .13 & -.09 & .14 & -.07 & .14 & -.07 \\
parents income & .11 & .01 & .10 & .00 & .10 & .02 & .10 & .02 \\
act score & .12 & .10 & .12 & .07 & .12 & .04 & .12 & .05 \\
hometown & .16 & .02 & .16 & .00 & .15 & .00 & .16 & .00 \\
policy prestige & & & .03 & $.31^{*}$ & .04 & $.24^{*}$ & .04 & $.25^{*}$ \\
policy status & & & & & .05 & $.15^{*}$ & .05 & $.17^{*}$ \\
policy esteem & & & & & & & .04 & .03 \\
$R^{2}$ & & .02 & & .12 & & .13 & & .13 \\
\hline
\end{tabular}

Note. $\mathrm{p}<.05^{*}$.

Tables 26 and 27 demonstrated that improvements in the perceptions of prestige may also have a significant effect on the rural and urban aspiring teacher population $(\mathrm{r}=.33, \beta=.38)$ deriving from households with annual incomes exceeding $\$ 100,000$, and those who have scored 21 or greater on the ACT. These results appear significant because they indicate that improvements in the perceptions of teaching's prestige may stabilize this 
population's career intentions. This population may be more likely to become teachers once the perception of teaching's prestige has improved. Moreover, these results suggest that improvements in the perception of teaching's prestige may limit consideration of early exit and ease some of the burdens of early teacher attrition.

Table 26. Bivariate correlation: aspiring teachers

The interaction variable includes policy intervention status $\mathrm{x}$ policy intervention esteem.

\begin{tabular}{|c|c|c|c|c|c|c|c|c|c|c|}
\hline & 1 & 2 & 3 & 4 & 5 & 6 & 7 & 8 & 9 & 10 \\
\hline 1. policy teach & - & & & & & & & & & \\
\hline 2. policy prestige & $.33^{*}$ & - & & & & & & & & \\
\hline 3. policy status & $.23 *$ & $.69^{*}$ & - & & & & & & & \\
\hline 4. policy esteem & .09 & $.55^{*}$ & $.67 *$ & - & & & & & & \\
\hline 5. gender & $-.19 *$ & -.06 & -.04 & -.11 & - & & & & & \\
\hline 6. act score & .11 & $.33 *$ & $.37 *$ & $.23 *$ & .03 & - & & & & \\
\hline 7. hometown & .00 & .12 & .07 & .07 & -.02 & .03 & - & & & \\
\hline 8. main source & -.06 & -.07 & -.07 & -.08 & .06 & .13 & .08 & - & & \\
\hline 9. parents income & .06 & -.01 & .03 & -.01 & -.08 & .04 & $-.21^{*}$ & .10 & - & \\
\hline 10. interaction & .08 & $-.22 *$ & $-.17 *$ & $-.34 *$ & $.35 *$ & .07 & -.02 & .05 & -.02 & - \\
\hline
\end{tabular}

Note. $\mathrm{p}<.05^{*}$.

Table 27. Hierarchal linear regression: aspiring teachers

The interaction variable includes policy intervention status $\mathrm{x}$ policy intervention esteem.

\begin{tabular}{lllllllllll}
\hline \multirow{2}{*}{ Predictors } & \multicolumn{1}{l}{ Step 1 } & \multicolumn{1}{c}{ Step 2 } & \multicolumn{3}{c}{ Step 3 } & \multicolumn{3}{c}{ Step 4 } & \multicolumn{3}{c}{ Step 5 } \\
\cline { 2 - 11 } & SE & $\beta$ & SE & $\beta$ & SE & $\beta$ & SE & $\beta$ & SE & $\beta$ \\
\hline main source & .20 & -.08 & .19 & -.04 & .19 & -.04 & .19 & -.05 & .19 & -.04 \\
parents income & .63 & .06 & .61 & .05 & .61 & .05 & .61 & .05 & .60 & .05 \\
gender & .49 & $-.20^{*}$ & .47 & -.18 & .48 & -.18 & .47 & $-.19^{*}$ & .49 & $-.26^{*}$ \\
act score & .28 & .14 & .29 & .03 & .30 & .04 & .30 & .03 & .20 & .00 \\
hometown & .38 & .01 & .37 & -.03 & .37 & -.03 & .37 & -.03 & .36 & -.04 \\
policy prestige & & & .04 & $.31^{*}$ & .05 & $.32^{*}$ & .06 & $.35^{*}$ & .05 & $.38^{*}$ \\
policy status & & & & & .07 & -.01 & .08 & .10 & .07 & -.12 \\
policy esteem & & & & & & & .06 & -.20 & .06 & .20 \\
interaction & & & & & & & & & .03 & $.22 *$ \\
$R^{2}$ & & .06 & & .14 & & .15 & & .17 & & .20 \\
\hline
\end{tabular}

Note. $\mathrm{p}<.05^{*}$.

\section{Discussion}

The results from this study illustrated that an occupation's semantic status is unbalanced when a society holds negative perceptions of at least one of prestige's components, financial and image, as well as status and esteem (Figure 3). This instability can lead to a limited interest in teaching and shortages in a quality workforce, which seems to be the current state of the teaching career in the United States. The data demonstrated that high school seniors and college undergraduates may hold positive perceptions of teaching's status. In fact, perceptions of teaching's status may be higher than that of other public service occupations (Hoyle, 2001). This seems to be good news, but the results also indicated that perceptions of teaching's status may plateau beneath professions perceived commonly to hold high status, and teaching's semantic status' instability may be a reason for this limitation. While perceptions of teaching's status appear promising, esteem's negative implications and its negative interaction with prestige's image and financial components may prevent teaching from achieving semantic status. 


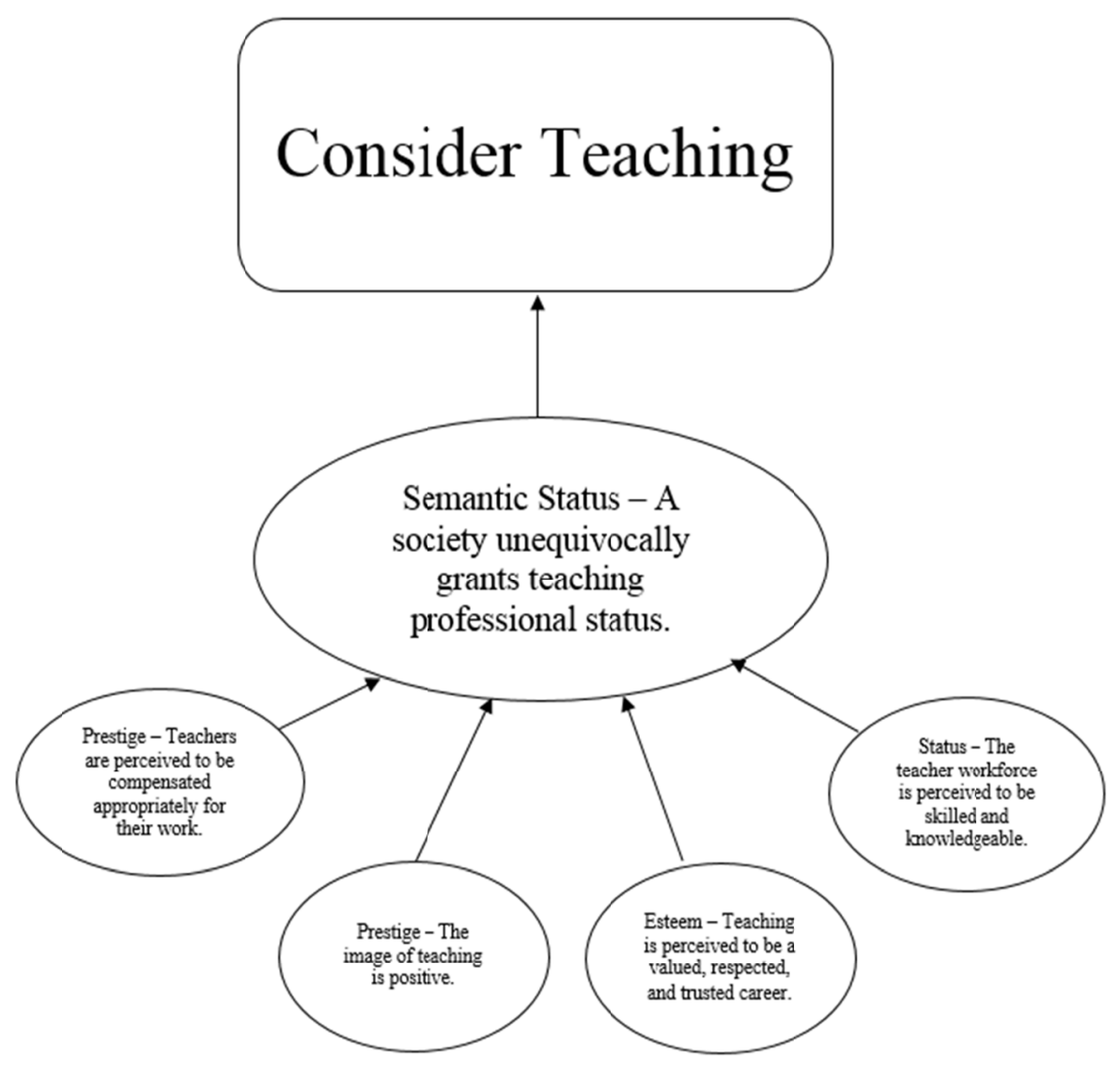

Figure 3. Conceptual framework that was developed from the results of the study

Semantic status may be similar to a four-legged stool. Semantic status becomes unsteady when one or more of its essential components are absent.

In contrast, an occupation may realize semantic status when negative perceptions of its prestige (financial and image components), status, and esteem do not persist. In fact, an occupation's semantic status may strengthen when a society holds positive perceptions of one or more of these elements. This stability can generate great interest in an occupation and lead to the development of a quality workforce. This theory appears to portray the state of teaching in nations such as Finland, Taiwan, Singapore, and South Korea, in which teaching's semantic status has afforded the opportunity to attract the brightest and most capable students into teaching (Darling-Hammond, 2017; Sahlberg, 2015). With highly skilled teachers, these nations have developed a stable and quality teacher workforce able to produce robust student achievement. The results have generated world-wide interest, but more importantly, they demonstrate that a strong teacher workforce is an essential component of student learning (Sahlberg, 2015).

\subsection{The Erosion of Esteem}

It is plausible that the media's representation of teachers, consistent political criticism, poor teacher compensation, and a public that undervalues teaching may be eroding the perceptions of teaching's esteem. Comments such as "the decline of American education has long been a national embarrassment" may sell magazines and newspapers, but the discourse may also chip away at the career's esteem (Draper, 2010, p. 1). Negative comments on the part of governmental leaders and the decades-long political war on public education could also be taking a toll (Reilly, 2018). Combined with such negative discourse, poor teacher compensation seems to be eroding teaching's esteem. Low salaries signal that a teacher's work in educating the nation's children is undervalued, which may significantly affect its ability to fill its teacher pipelines.

Esteem's implications may also be complicating efforts to recruit prospective teachers. Maslow (1943) asserted 
that this is a natural response because "all people in our society have a need or desire for a stable, firmly based, high evaluation of themselves, for self-respect, or self-esteem, and for the esteem of others" (p. 381). His work illustrates that an esteemed career satisfies the needs for both professional and personal validation, and serves as a foundation in the quest for "reputation or prestige" (p. 382). This quest may be a driving force in career and personal life decisions, but it also can be a chief deterrent. It is plausible that many high school seniors and college undergraduates are unwilling to teach because they perceive teaching as a career that limits their individual abilities to reach their fullest personal and professional potentials (McClelland, 2001; Petty, 2014).

These assumptions may be the reason that high school seniors and college undergraduates who score 29 or greater on the ACT may be less likely to consider teaching than those who score in the lower deciles (Tables 28, 29 and 30). Perceptions of teaching's status may encourage this population to consider teaching, but perceptions of esteem, and its interaction with prestige's financial component, and the main sources used to learn about teaching, may deter its members (Tables 19 and 20). This population often avoids teaching because they believe that the career will prevent them from reaching their fullest potential. Further, they are unwilling to sacrifice their basic financial needs for a career, and are more inclined to elect occupations consistent with their financial goals (Wan, Wong, \& Kong, 2014).

Table 28. ANOVA: ACT scores and teaching considerations

\begin{tabular}{llllll}
\hline Variable & SS & df & MS & F & p \\
\hline $\begin{array}{l}\text { how much consider teach } \\
\text { act score }\end{array}$ & 356.95 & 1034 & 89.24 & 11.10 & $.00^{*}$ \\
\hline
\end{tabular}

Note. $\mathrm{p}<.05 *$.

Table 29. ANOVA descriptive statistics

\begin{tabular}{lllll}
\hline Variable & Mean & SD & n & Range \\
\hline how much consider teach & & & & \\
seniors and undergraduates scoring 17 or less on the ACT & 3.06 & 2.96 & 79 & $0-8$ \\
seniors and undergraduates scoring in the 18 to 20 range on the ACT & 5.08 & 2.87 & 132 & $0-8$ \\
senior and undergraduates scoring in the 21 to 24 range on the ACT & 4.69 & 2.87 & 402 & $0-8$ \\
seniors and undergraduates scoring in the 25 to 28 range on the ACT & 4.55 & 2.88 & 254 & $0-8$ \\
seniors and undergraduates scoring 29 or higher on the ACT & 3.58 & 2.60 & 172 & $0-8$ \\
\hline
\end{tabular}

Table 30. Bonferroni post-hoc analysis

\begin{tabular}{lllll}
\hline Comparison & $\begin{array}{l}\text { Mean Differences } \\
\text { in Perceptions }\end{array}$ & Std. Error & Lower Bound & Upper Bound \\
\hline $\begin{array}{l}\text { seniors and undergraduates scoring 29 or higher vs. } \\
\text { seniors and undergraduates scoring 18-20 }\end{array}$ & $-1.49^{*}$ & .33 & -2.42 & -.57 \\
$\begin{array}{l}\text { seniors and undergraduates scoring 29 or higher vs. } \\
\text { seniors and undergraduates scoring 21-24 }\end{array}$ & $-1.11^{*}$ & .26 & -1.84 & -.39 \\
$\begin{array}{l}\text { seniors and undergraduates scoring 29 or higher vs. } \\
\text { seniors and undergraduates scoring 25-28 }\end{array}$ & $-.97^{*}$ & .28 & -1.75 & -.18 \\
\hline p $\mathrm{p}<.05^{*}$. & & & \\
\hline
\end{tabular}

Table 1 presents that $56 \%$ of the total population reported that they acquired information about teaching from their own teachers, administrators, and school counselors. These data, in concert with main source's interaction with esteem and prestige's financial component, demonstrated that the implications of low teacher morale may negatively influence high school seniors and college undergraduates who score in the upper deciles of the ACT (Lawver \& Torres, 2011). Figure 4 illustrates the discontent within the teacher workforce, in which the majority of 4,275 teachers reported that they have considered leaving teaching (Klimek, 2018). This evidence supports commentary that suggests teacher morale may be at its lowest in decades. It is plausible that this discontent may be modeled in the classroom and discourage a large number of high achievers from considering teaching (Sutcher et al., 2016).

The results displayed that low teacher morale may prompt practicing teachers to discourage those who score in the upper deciles of the ACT from considering teaching. Figure 5 displays the results of 4,275 teachers' reports 
of the degree to which they would encourage others to enter the career. The results demonstrate that $54 \%$ of teachers reported some degree of discouragement, while $45 \%$ reported some degree of encouragement. The largest differences were in the percentage of teachers who would strongly encourage others to teach (4\%) versus those who would not (17\%: Klimek, 2018). This may be problematic considering the occupation's nature. Teaching is the single occupation that interacts with the majority of a population. This uniqueness can serve as a strong recruitment tool, but it also can pose problems. In its current state, it appears that teachers may serve more as a deterrent than a recruitment tool.

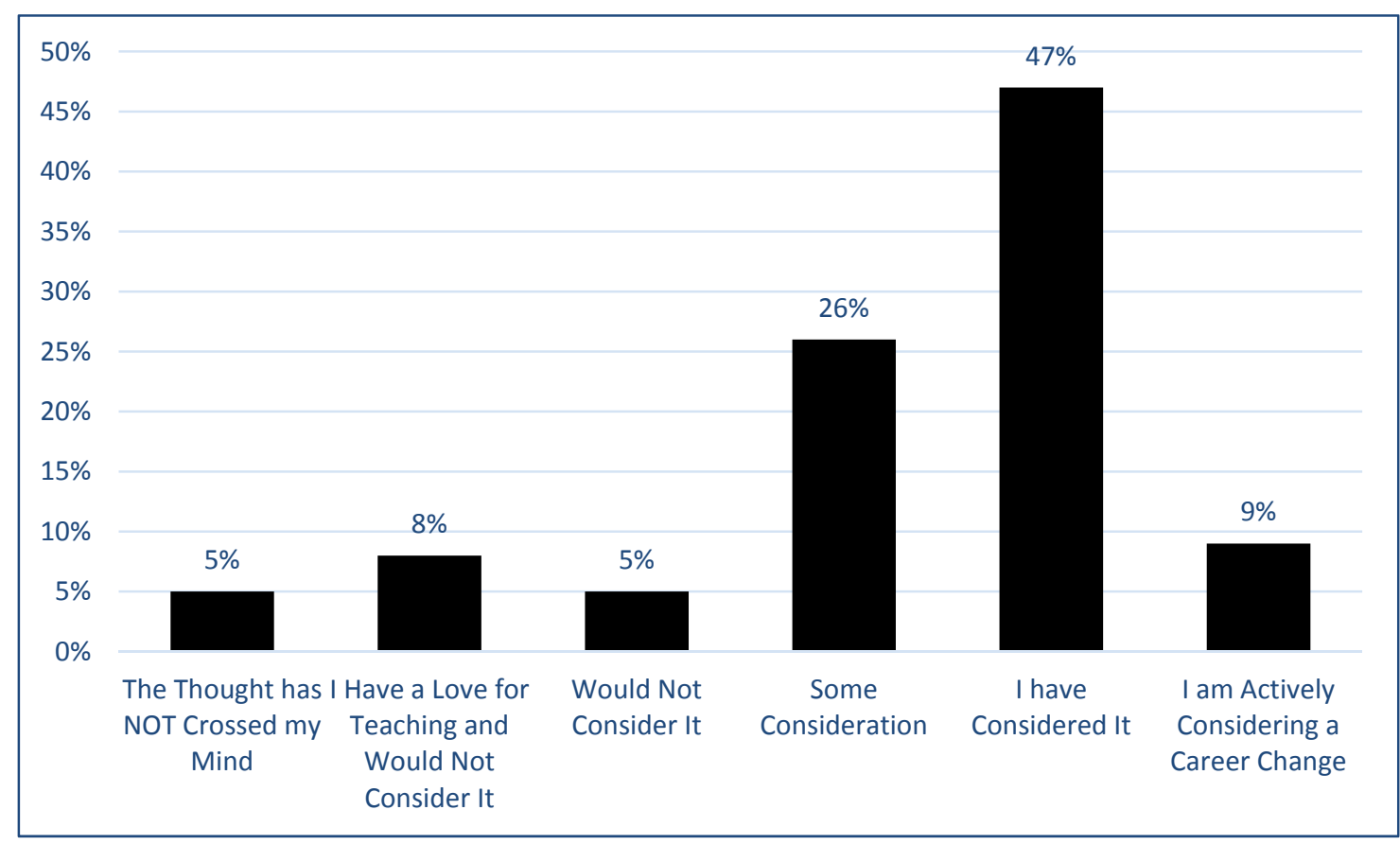

Figure 4. To what degree have you considered leaving? (Klimek, 2018)

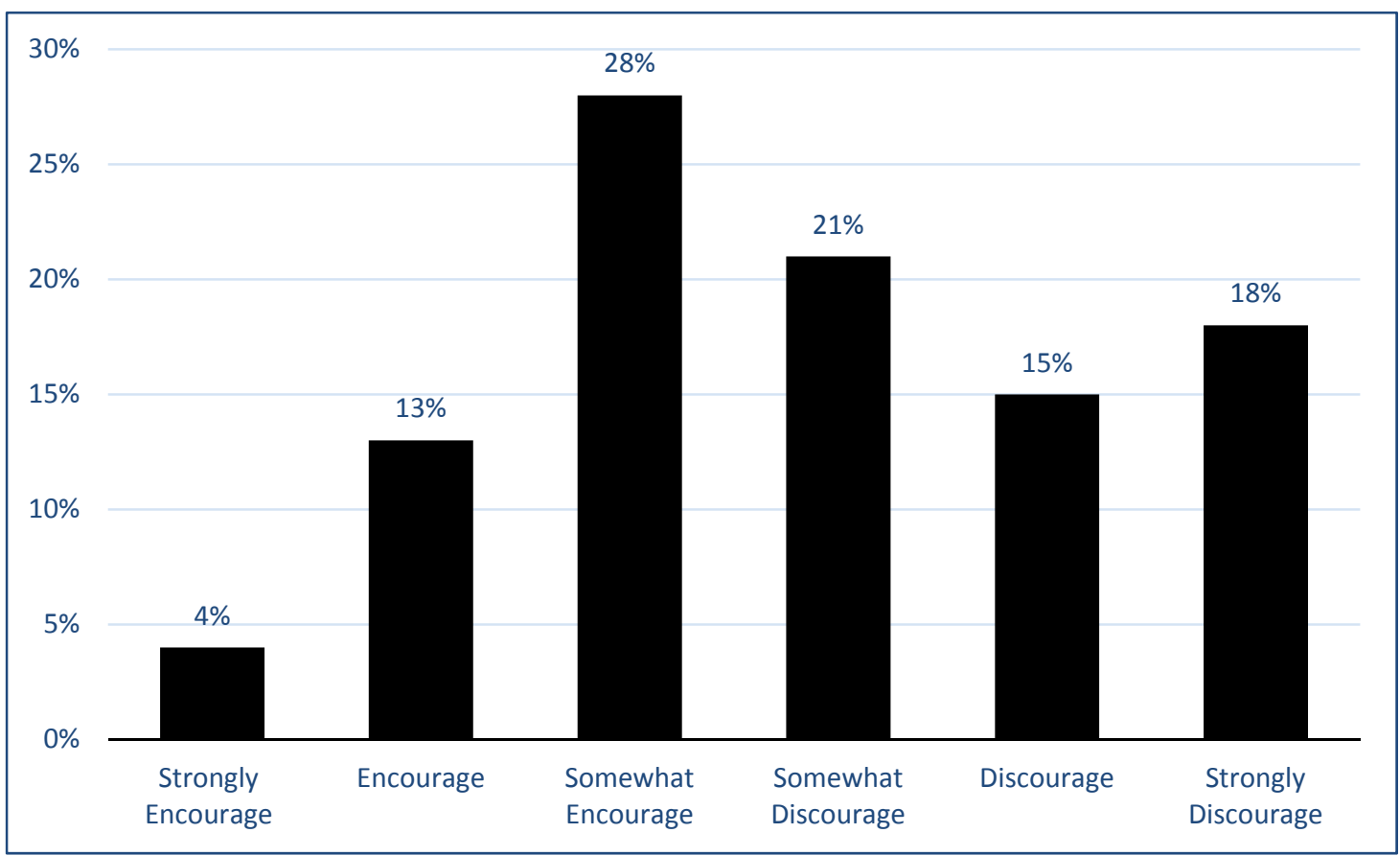

Figure 5. To what degree would you encourage others to enter teaching? (Klimek, 2018) 
The results indicated that the aspiring teacher population may not be immune from the negative implications of teaching's esteem (Tables 17 and 18). Like others, perceptions of teaching's status may be an attractive component, but esteem's interaction with prestige's financial component may exert similar effects. Poor compensation and its reflection of teaching's devaluation may be placing this population at-risk of choosing alternative careers.

These results raise questions as to the reasons for early teacher attrition. Previous research has reported that the foundation of early teacher attrition may be laid within the first five years of a teacher's career (Ingersoll, Merrill, \& Stuckey, 2014; Parham \& Gordon, 2011; Reilly, 2018). Indeed, a large body of evidence illustrates this phenomenon, but the results reported here suggest that the foundations of early teacher attrition may be found at the preservice teacher level. It could be that the perceptions of poor compensation and teaching's devaluation begin to motivate thoughts of early attrition before new teachers accept their first teaching assignment. Once exposed to the career's realities, it is plausible that thoughts of early attrition will come to fruition.

The erosion of teaching's esteem appears to destabilize teaching's semantic status. The results demonstrated consistently that positive perceptions of teaching's status may be planted firmly, but the component itself may be unable to support teaching's semantic status on its own. The evidence indicates that a career achieves semantic status when negative perceptions of its prestige (financial and image), status, and esteem do not persist. This may be the reason society has not yet granted teaching semantic status, and forecasts into the future predict that the status quo will remain unless the perceptions of teaching's esteem are addressed. Indeed, these realities appear grim, but the results may demonstrate the promise of policy that is designed to support the perceptions of teaching's prestige, status, and esteem.

\subsection{Implications of International Policy}

Several international education policies were embedded within this present study, and a number of analyses were performed to investigate the effect each may have on teaching's semantic status in America. Participants had the opportunity to view the perceptions of teaching's prestige, status, and esteem through a different lens, and the results appear encouraging. The data revealed no negative implications of teaching's prestige, status, and esteem, and that greater numbers of high school seniors and college undergraduates may be interested in teaching. These results demonstrated that the implementation of international policy may be a reason for teaching to realize semantic status in the United States, which may lead high school seniors and college undergraduates to be more willing to teach, and will thereby ease the burdens of the teacher shortage.

The data revealed that the post-policy perceptions of prestige and its interaction with status may significantly affect high school senior and college undergraduates' post-policy teaching considerations. These results indicated that compensation may moderate a career's status. More importantly, they illustrated that competitive teacher compensation can no longer be left for debate, because a career's prestige and status are the primary rewards that attract individuals to any occupation (Zhao \& Zhou, 2008). However, political discourse foretells that prestige may be the component that will elicit the most debate, as teacher compensation depends directly on public tax dollars (Hoyle, 2001). Regardless of the political firestorms that may erupt, the teacher workforce's quality relies on policymakers who are willing to seriously consider developing strategies to strengthen teaching's prestige. In today's contemporary labor market, policymakers can no longer can afford to compensate teachers poorly, because poor compensation will not allow teaching to realize semantic status. Without semantic status, policymakers run the risk of placing large numbers of inadequate teachers in the nation's classrooms who are incapable of preparing youth for the demands of a global economy (Wan, Wong, \& Kong, 2014).

\subsection{Recommendations for State Agencies}

The data presented in this study demonstrate the need for state education agencies to inform legislators of the effects teaching's prestige, status, and esteem have on the teacher shortage, the teacher workforce's quality, and student achievement. Lawmakers and education leaders must understand that the contemporary labor market does not compel graduates to select careers that the government and general public undervalue, as reflected in poor compensation and negative rhetoric. Officials need to be aware that these perceptions are the current state of teaching, and are causing many high school seniors and college undergraduates to lose interest in considering the career. They must realize that this limited interest in the career weakens the teaching workforce, limits student achievement, reduces economic prosperity, and damages the nation's health overall. Policymakers must realize that a proactive investment in its teacher workforce is wiser than spending tax dollars to mend social ills that develop when the public is inadequately educated.

Further, state task forces comprised of state legislators and education officials, teachers, university faculty, and other public stakeholders should be assembled to review and prioritize state revenue streams. Such task forces 
should identify appropriate revenue sources that can be directed to teacher compensation. Once sources are identified, it is recommended that the task forces use a variety of media sources, public listening sessions, and other platforms to communicate teaching's current state, and its multiple implications.

It is critical that these taskforces emphasize teaching's complexities and demands. America's classrooms are experiencing not only growing numbers of students with mental health concerns, but those who are impoverished and have limited English proficiency. The taskforces must communicate that these complexities require a strong teacher workforce that is able to cope effectively with these challenges, and produce high student achievement. They also must communicate that this will require an investment in teacher compensation.

An additional task force should be formed once legislators are committed to making appropriate investments in their state's teacher workforce. This task force's primary goal would be to increase rigor in teacher education programs and teacher licensing requirements. These taskforces composed of legislators, education officials, teachers, university faculty, state licensing officials, and other public stakeholders combined should work with university faculty to design rigorous courses at both the undergraduate and graduate levels. In addition, it is recommended that taskforces develop policy to require preservice teachers to participate in yearlong paid internships and earn Master's degrees before receiving teacher licensure. This policy will elevate teaching's status, promote greater interest in teaching, and prepare teachers better for teaching's rigorous demands. This advanced preparation will improve teacher efficacy, and ease the burdens of early teacher attrition.

Finally, boards of educators who are not union affiliated should be established at the state and federal levels to ensure that teachers are part of the policymaking process. Such boards should consist of teachers who are elected by constituencies and policymakers assigned by legislative bodies. These boards should hold the authority to draft, critique, and propose legislation related to education.

\subsection{Recommendations for School Districts}

School district officials should work with local media sources to share the successes that occur in their schools. They can flood the media with a combination of success stories and teacher recognition. This practice will reestablish the public's trust in its teachers, and provide the opportunity to understand the type of professional work that occurs in their children's schools.

School districts should also provide release time for teachers to participate in local chamber of commerce and city council meetings, and other appropriate events. This time will provide teachers with opportunities to engage larger audiences and hold discussions about their professional work. They will also allow teachers to clarify misconceptions, and modify the general public's perceptions of their career.

Lastly, school boards, educational leaders, and teachers are recommended to collaborate to restructure teacher salary schedules to reflect years of service, professionalism, and areas of expertise. Salary schedules could be designed to allow teachers to move both vertically and horizontally through the schedule. Vertical movements should be based on years of experience, horizontal movements on rank (e.g., instructor, master teacher). This design allows teachers to earn additional compensation for years of service, but also encourages them to strive for professional improvement. School districts should establish professional criteria for teachers to advance from one rank to the next (e.g., publishing educational research and gaining expertise in mental health), and provide significant compensation for those who earn promotion.

\subsection{Recommendations for Further Research}

Further research should be conducted to investigate high school senior and college undergraduate populations from a variety of U.S. regions and foreign nations. The research should be replicated, but with the use of an abridged version of the present study's instrument. It is recommended that future research use the independent variables that loaded in this study, so that survey fatigue does not interfere with data collection.

Further research will lead to an established body of literature that demonstrates the effects teaching's prestige, status, and esteem have on populations of high school seniors and college undergraduates from a variety of U.S. regions and foreign nations. This research will provide policymakers and practitioners with a deep understanding of the way the aforementioned perceptions affect teaching decisions, and also will afford policymakers the opportunity to develop policy that targets specific U.S. and worldwide regions. This research will also provide a platform for regional, national, and worldwide discourse surrounding the issue of teacher shortages.

\section{Concluding Remarks}

The study's results demonstrated that perceptions of teaching's status may significantly influence high school seniors and college undergraduates. Although this is indeed encouraging, perceptions of status alone may not 
attract large numbers of young people to careers in teaching. Status requires support from prestige and esteem, but it appears that they are perceived negatively at present, and these negative perceptions are preventing teaching from realizing semantic status. Without semantic status, the nation will continue to experience challenges in filling the nation's classrooms with quality teachers.

The lack of an effective teacher workforce may place the nation's vital interests at-risk. The inability to hire quality teachers will lead public schools to be inflexible in their approaches and prevent them from reshaping their practices to meet the demands of the 21 st century. While this future appears bleak, the results indicated that policy designed to improve the perceptions of teaching's prestige, status, and esteem may be a reason for teaching to realize semantic status, which may produce a greater interest in teaching, and persuade greater numbers of talented individuals to consider a teaching career.

\section{References}

ACT. (2018). The condition of college and career readiness. Retrieved from https://www.act.org/content/dam/act/unsecured/documents/cccr2018/National-CCCR-2018.pdf

Akiba, M., LeTendre, G., \& Scribner, J. (2007). Teacher quality, opportunity gap, and national achievement in 46 countries. Educational Researcher, 36, 369-387. https://doi.org/10.3102/0013189X07308739

Aragon, S. (2016). Teacher shortages: What we know. Education Commission of the States. Retrieved from https://eric.ed.gov/?id=ED565893

Auguste, B., Kihn, P., \& Miller, M. (2010). Closing the talent gap: Attracting and retaining top third graduates to careers in teaching. Retrieved from McKinsey and Company website http://mckinseyonsociety.com/downloads/reports/Education/Closing_the_talent_gap.pdf

Barber M., \& Mourshed M. (2007). How the world's best-performing school systems come out on top. Retrieved from

https://www.mckinsey.com/industries/social-sector/our-insights/how-the-worlds-best-performing-school-sy stems-come-out-on-top

Braun, H. I., Wang, A., Jenkins, F., \& Weinbaum, E. (2006). The black-white achievement gap: Do state policies matter? Education Policy Analysis Archives, 14(8), 1-110. https://doi.org/10.14507/epaa.v14n8.2006

Breaux, A., \& Wong, H. (2003). New teacher induction: How to train, support, and retain new teachers. Mountain View, CA: Harry Wong Publications.

Bushaw, W. J., \& Lopez, S. J. (2011). Betting on teachers. Phi Delta Kappan, 93(1), 9-26. https://doi.org/10.1177/003172171109300103

Carey, K. (2017). Dismal voucher results surprise researchers as Devos era begins. New York Times. Retrieved from

http://68.77.48.18/RandD/Other/Dismal\%20Voucher\%20Results\%20Surprise\%20Researchers\%20-\%20NY T.pdf

Chan, Y. H. (2003). Biostatistics 101: Data presentation. Singapore Medical Journal, 44, 280-285.

Clotfelter, C., Ladd, H., \& Vidgor, J. (2007). Achievement: Longitudinal analysis with student fixed effects. Economics of Education Review, 26, 673-682. https://doi.org/10.1016/j.econedurev.2007.10.002

Darling-Hammond, L. (2017). Teacher education around the world: What can we learn from international practice? European Journal of Teacher Education, 40, 291-309. https://doi.org/10.1080/02619768.2017.1315399

Darling-Hammond, L., \& Berry, B. (2006). Highly qualified teachers for all. Educational Leadership, 64(3). Retrieved

from https://www.researchgate.net/profile/Linda_Darling-Hammond/publication/234670054_Highly_Qualified_ Teachers_for_All/ links/0a85e537c69b3b83e5000000.pdf

Darling-Hammond, L., Furger, R., Shields, P., \& Sutcher, L. (2016). Addressing California's emerging teacher shortage: An analysis of sources and solutions. Learning Policy Institute. Retrieved from https://learningpolicyinstitute.org/wp-content/uploads/2016/03/LPI-Report-AddressingCA_TeacherShortag e.pdf.

Darling-Hammond, L., \& Rothman, R. (2015). Teaching in the flat world: Learning from high-performing systems. New York: Teachers College Press. 
DeNisco, A. (2015). Teacher shortage at 'crisis' levels. District Administration. Retrieved from http://www.districtadministration.com/article/teacher-shortage- $\% \mathrm{E} 2 \% 80 \% 98 \mathrm{crisis} \% \mathrm{E} 2 \% 80 \% 99$-levels

Dillon, S. (2011, March 16). Study: U.S. must raise status of its teachers. The New York Times. Retrieved from http://go.galegroupcom.ezproxy.library.und.edu/ps/i.do?p=EAIM\&sw=w\&u=ndacad_58202zund\&v=2.1\&i $\mathrm{t}=\mathrm{r} \& \mathrm{~d}=$ GALE57CA252505195\&asid $=21 \mathrm{f92e} 6913 \mathrm{~d} 2662 \mathrm{ad} 837 \mathrm{ea} 4 \mathrm{f} 1179 \mathrm{ad} 3$

Dolton, P., \& Marcenaro-Guiterrez, O. (2013). Varkey GEMS foundation global teacher status index. Gems Education. Retrieved

from http://sro.sussex.ac.uk/63812/1/2013\%2BGlobal\%2BTeacher\%2BStatus\%2BIndex\%2BI.pdf

Draper, J. (2010). Crucial conversations about America's schools. Alexandria, VA: Educational Research Service.

DuFour, R., \& Mattos, M. (2013). How do principals really improve schools? Principalship, 70(7), 34-40.

Fleischman, H., Hopstock, P., Pelczar, M., \& Shelley, B. (2010). Highlights from PISA 2009: Performance of U.S. 15-year-old students in reading, mathematics, and science literacy in an international context. National Center for Education Statistics. Retrieved from https://nces.ed.gov/pubsearch/pubsinfo.asp?pubid=2011004

Fuller, C., Goodwyn, A., \& Francis-Brophy, E. (2013). Advanced skills teachers: professional identity and status. Teachers and Teaching, 19, 463-474. https://doi.org/10.1080/13540602.2013.770228

Fwu, B., \& Wang, H. (2002). The social status of teachers in Taiwan. Comparative Education, 38, 211-224. https://doi.org/10.1080/03050060220140584

Gerckens, K. (2016). Teacher Shortage in California getting worse: Ventura County offers incentives to new teachers. Retrieved from http://www.keyt.com/news/california/teacher-shortage-in-california-getting-worse_20160830074904659/65 256807

Goldstein, R. (2011). Imaging the frame: Media representations of teachers, their unions, NCLB, and education reform. Educational Policy, 25, 543-576. https://doi.org/10.1177/0895904810361720

Goyder, J. (2005). The dynamics of occupational prestige: 1975-2000. Canadian Review of Sociology \& Anthropology, 42, 1-23. https://doi.org/10.1111/j.1755-618X.2005.tb00788.x

Guha, R., Hyler, M., \& Darling-Hammond, L. (2017). The teacher residency: A practical path to recruitment and retention. American Educator, 4(1), 31-34. https://doi.org/10.1177/0031721717708292

Hanushek, E., Peterson, P., \& Woessmann. (2012). Achievement growth: International and U.S. state trends in student performance. Retrieved from http://hanushek.stanford.edu/sites/default/files/publications/Hanushek\%2BPeterson\%2BWoessmann\%2020 12\%20PEPG.pdf

Hanushek, E., \& Rivkin, S. (2010). Generalizations about using value-added measures of teacher quality. American Economic Review, 100, 267-271. https://doi.org/10.1257/aer.100.2.267

Hargreaves, L. (2009). The status and prestige of teachers and teaching. International Handbook of Research on Teachers and Teaching, 217-229. https://doi.org/10.1007/978-0-387-73317-3_13

Hargreaves, L., Cunningham, M., Everton, T., Hansen, A., Hopper, B., McIntyre, D., \& Turner, P. (2007). The status of teachers and the teaching profession in England: Views from inside and outside the profession. University of Cambridge. Retrieved from https://www.educ.cam.ac.uk/research/projects/teacherstatus/Evidencebase_25Jan07_print_ready_version.pd $\mathrm{f}$

Hoyle, E. (2001). Teaching prestige, status, and esteem. Educational Management Administration \& Leadership, 29, 139-152. https://doi.org/10.1177/0263211X010292001

Hsiou-Huai, W., \& Chin-Chun H. (2016) Those who can, teach: the academic quality of preservice students in teacher education programmes in Taiwan. Asia-Pacific Journal of Teacher Education, 44(1), 66-79. https://doi.org/10.1080/1359866X.2014.987722

Ingersoll, R., \& Merrill, E. (2011). The status of teaching as a profession. University of Pennsylvania Scholarly Commons. Retrieved from http://repository.upenn.edu /gse_pubs/221

Ingersoll, R., Merrill, L., \& Stuckey, D. (2014). Seven trends: The transformation of the teaching force. 
Consortium for Policy Research in Education. Retrieved from http://www.cpre.org/sites/default/files/Workingpapers

Ingersoll, R., \& Perda, D. (2008). The status of teaching as a profession. Retrieved from http://www.gse.upenn.edu/pdf/rmi/SSSAE-RMI-2008.pdf

Kastberg, D., Chan, Y., \& Murray, G. (2017). Performance of U.S. 15-year-old students in science, reading, and mathematics literacy in an international context: First look at PISA 2015. National Center for Education Statistics. Retrieved from https://eric.ed.gov/?id=ED570968

Klimeks, S. (2018). Do the perceptions of teaching's prestige, status, and esteem impact early teacher attrition? Unpublished raw data.

Lankford, H., Loeb, S., McEachin, A., Miller, L., \& Wyckoff, J. (2014). Who enters teaching? Encouraging evidence that the status of teaching is improving. Educational Researcher, 43(9), 444-553. https://doi.org/10.3102/0013189X14563600

Lawver, R., \& Torres, R. (2011). Determinants of pre-service students' choice to teach secondary agricultural education. Journal of Educational Education, 52(1), 61-71. https://doi.org/10.5032/jae.2011.01061

Lim, K. M. (2014). Teacher education \& teaching profession in Singapore. Paper presented at the International Conference on the Teaching Profession in ASEAN, Bangkok, Thailand.

Mackenzie, N. (2007). Teacher morale: More complex than we think? Australian Educational Researcher, 34(1), 89-104. https://doi.org/10.1007/BF03216852

Maslow, A. H. (1943). A Theory of Human Motivation. Psychological Review, 50(4), $370-396$. https://doi.org/10.1037/h0054346

McClelland, D. C. (2001). Achievement motivation. In W. E. Natemeyer \& J. T. McMahon (Eds.), Classics of organisational behavior (3rd ed., pp. 73-80). Long Grove, IL: Waveland Press, Inc.

McLeskey, J., \& Billingsley, B. (2008). How does the quality and stability of the teaching force influence research-to-practice gap? A perspective on the teacher shortage in special education. Remedial and Special Education, 29, 293-305. https://doi.org/10.1177/0741932507312010

Mensah, F. (2011). The DESTIN: Preservice teachers' drawings of the ideal elementary science teacher. School Science and Mathematics, 111, 379-388. https://doi.org/10.1111/j.1949-8594.2011.00103.x

National Center for Education Statistics. (2016a). The Condition of Education. Retrieved from https://nces.ed.gov/pubs2016/2016144.pdf

OECD. (2005). Teachers matter: Attracting, developing, and retaining effective teachers. Retrieved from https://www.oecd.org/edu/school/34990905.pdf

OECD. (2010). Lessons for the United States. Retrieved from https:/www.oecd.org/unitedstates/46581520.pdf

OECD. (2015). Education at a glance: OECD indicators. OECD Publishing. https://doi.org/10.1787/eag-2015-en

Paine, S., \& Schleicher, A. (2010). What the U.S. can learn from the world's most successful education reform efforts. Retrieved from http://68.77.48.18/RandD/ Other/ McGraww-Hill\%20PISA\%20Report.pdf

Parham, J., \& Gordon, S. (2011). Moonlighting: A harsh reality for many teachers. Phi Delta Kappan, 92(5), 4751. https://doi.org/10.1177/003172171109200511

Perda, D. (2013). Transitions into and out of teaching: A longitudinal analysis of early career teacher turnover. Retrieved from ProQuest Digital Dissertations (1444146830).

Petty, T. (2014). Motivating first-generation students to academic success and college completion. College Student Journal, 48(2), 257-264.

Pike, M. (2014). The perceptions of teacher status and impact on the American educational system. Baylor University, Waco, TX. Retrieved from https://baylor-ir.tdl.org/baylor-ir/bitstream/handle/2104/9009/Meagan\%20Pike\%20Honors\%20Thesis.pdf?s equence $=2 \&$ is Allowed $=\mathrm{y}$

Podgursky, M., Monroe, R., \& Watson, D. (2004). The academic quality of public school teachers: An analysis of entry and exit behavior. Economics of Education Review, 23, 507-518. https://doi.org/10.1016/j.econedurev.2004.01.005 
Programme for International Student Assessment (PISA) [brochure]. (2014). Retrieved from http://www.oecd.org/pisa/aboutpisa/PISA-trifold-brochure-2014.pdf

Reback, R. (2008). Teaching to the rating: School accountability and the distribution of student achievement. Journal of Public Economics, 92, 1394-1415. https://doi.org/10.1016/j.jpubeco.2007.05.003

Reilly, K. (2018, Sept. 13). 13 stories of life on a teacher's salary. Retrieved from https://www.yahoo.com/news/13-stories-life-teacher-apos-100043101.html

Rivkin, S., Hanushek, E., \& Kain, J. (2005). Teachers, schools, and academic achievement. Econometrica, 73, 417-458. https://doi.org/10.1111/j.1468-0262.2005.00584.x

Rockoff, J. (2004). The impact of individual teachers on student achievement: Evidence from panel data. American Economic Review, 94, 247-252. https://doi.org/10.1257/0002828041302244

Ronfeldt, M., Loeb, S., \& Wyckoff, J. (2013). How teacher turnover harms student achievement. American Educational Research Journal, 50(1), 4-36. https://doi.org/10.3102/0002831212463813

Ronfeldt, M., \& McQueen, K. (2017). Does new teacher induction really improve retention? Journal of Teacher Education, 68, 394-410. https://doi.org/10.1177/0022487117702583

Sahlberg, P. (2015). Finnish lessons 2.0: What can the world learn from educational change in Finland (2nd ed.). New York: Teachers College Press.

Sanders, W., \& Horn, S. (1998). Research findings from the Tennessee Value-Added Assessment System (TVAAS) database: Implications for educational evaluation and research. Journal of Personnel Evaluation in Education, 12, 247-256. https://doi.org/10.1023/A:1008067210518

Sanders, W., \& Rivers, J. (1996). Cumulative and residual effects of teachers on future student academic achievement. University of Tennessee Value-Added Research and Assessment Center. Retrieved from http://www.cgp.upenn.edu/pdf/Sanders_Rivers -TVASS_teacher\%20effects.pdf

Seongja, J. (2008). English education and teacher education in South Korea. Journal of Education for Teaching, 34, 371-381. https://doi.org/10.1080/02607470802401594

Simola, H. (2005). The Finnish miracle of PISA: Historical and sociological remarks on teaching and teacher education. Comparative Education, 41, 455-470. https://doi.org/10.1080/03050060500317810

Startz, D. (2016). Teacher pays around the world. Brown Center Chalkboard. Retrieved from https://www.brookings.edu/blog/brown-center-chalkboard/2016/06/20/teacher-pay-around-the-world/

Sutcher, L., Darling-Hammond, L., \& Carver-Thomas, D. (2016). A coming crisis in teaching? Teacher supply, demand, and shortages in the U.S. Learning Policy Institute. Retrieved from https://learningpolicyinstitute.org/sites/ default/files/product files/National_Teacher_Supply_ Demand_DC_9.15.16.pdf

Swetnam, L. (1992). Media distortion of the teacher image. Clearing House: A Journal of Educational Strategies, Issues, and Ideas, 66(1), 30-32. https://doi.org/10.1080/00098655.1992.9955921

Towse, P., Kent, D., Osaki, F., \& Kirua, N. (2002). Non-graduate teacher recruitment and retention: Some factors affecting teacher effectiveness in Tanzania. Teaching and Teacher Education, 18, 637-652. https://doi.org/10.1016/S0742-051X(02)00024-0

Treiman, D. (1977). Occupational prestige in comparative perspective. New York: Academic Press.

Wan, Y., Wong, I., \& Kong, W. (2014). Student career prospect and industry commitment: The roles of industry attitude, perceive social status, and salary expectations. Tourism Management, 40, 1-14. https://doi.org/10.1016/j.tourman.2013.05.004

Witte, J. (2016). Evaluating Voucher Programs: the Milwaukee Parental Choice Program. Retrieved from https://files.eric.ed.gov/fulltext/ED566983.pdf

Yuan, K., Vi-Nhuan, L., McCaffrey, D., Marsh, J., Hamilton, L., Stecher, B., \& Springer M. (2013). Incentive pay programs do not affect teacher motivation or reported practices. Education Evaluation and Policy Analysis, 35(1), 3-22. https://doi.org/10.3102/0162373712462625

Zhan, C. (2015). Money vs. prestige: Cultural attitudes and occupational choices. Labour Economics, 32, 44-56. https://doi.org/10.1016/j.labeco.2014.12.003

Zhang, G., \& Zeller, N. (2016). A longitudinal investigation of the relationship between teacher preparation and 
teacher retention. Teacher Education Quarterly, 43(2), 73-92.

Zhao, W., \& Zhou, X. (2008). Intraorganizational career advancement and voluntary turnover in a multinational bank in Taiwan. Career Development International, 13(5), 402-424. https://doi.org/10.1108/13620430810891446

\section{Copyrights}

Copyright for this article is retained by the author, with first publication rights granted to the journal.

This is an open-access article distributed under the terms and conditions of the Creative Commons Attribution license (http://creativecommons.org/licenses/by/4.0/). 